\title{
O desenho infantil como ferramenta de diagnóstico, percepção ambiental e avaliação de ações de educação ambiental
}

\section{Children's drawing as a diagnostic tool, environmental perception, and evaluation of environmental education actions}

\author{
El dibujo infantil como herramienta de diagnóstico, percepción ambiental y \\ evaluación de acciones de educación ambiental
}

\author{
Caetano Flores de Moura ${ }^{1}$ \\ Cibele Schwanke (in memoriam $)^{2}$
}

\begin{abstract}
Resumo
Chegamos a um ponto crítico com relação ao uso dos bens naturais, onde a poluição do ar, da água e da terra têm causado degradação da qualidade do ar, escassez de água, infertilidade dos solos e injustiças sociais. Diante desse cenário, destaca-se a gestão ambiental, o estudo da percepção ambiental e as ações de educação ambiental para amenizar esse contexto. O presente artigo apresenta os resultados de uma pesquisa, de cunho qualitativo, realizada a partir do desenvolvimento de ações de educação ambiental em uma comunidade em situação de risco e vulnerabilidade socioambiental. O diagnóstico sobre como as crianças participantes de um projeto percebem a natureza, antes e depois das ações de educação ambiental implementadas, foi realizado na tentativa de compreender as mudanças ocorridas em suas relações com o seu espaço e a natureza. Tendo em vista o público constituído por crianças de seis a oito anos, foram utilizados desenhos que, posteriormente, foram interpretados utilizando a análise de conteúdo. Como resultado da intervenção, identificou-se que os educandos passaram a se perceber como parte da natureza e agentes atuantes em seus espaços e que a relação e a percepção ambiental dos educandos mudou, passando de uma percepção ambiental descontextualizada com a realidade, para uma percepção ambiental contextualizada e participativa do meio ambiente.
\end{abstract}

Palavras-chave: Educação ambiental. Gestão ambiental. Desenho. Natureza.

\begin{abstract}
We have reached a critical point in relation to the use of natural resources, where air, water and land pollution have caused degradation of air quality, water scarcity, soil infertility and social injustices. In view of this scenario, environmental management, environmental perception and environmental education actions stand out to mitigate this context. This article presents the results of a qualitative research carried out based on the development of environmental education actions in a community at risk and in socio-environmental vulnerability. There was the diagnosis of how the children participating in a project perceive nature, before and after the environmental education implemented, to understand changes in their relationships with their space and nature. In view of the public composed of children from six to eight years old, drawings were used, which were then interpreted through content analysis. As a result of the intervention, it was identified that the students began to perceive themselves as part of nature and the agents that act in their spaces and that the relationship and the environmental perception of the students changed, going from an environmental perception outside of context with reality, to a contextualized and participative environmental management perception.
\end{abstract}

Keywords: Environmental education. Environmental management. Drawing. Nature.

\footnotetext{
${ }^{1}$ Tecnólogo em Gestão Ambiental. Mestrando no Programa de Pós-Graduação em Desenvolvimento Rural, Universidade Federal do Rio Grande do Sul. E-mail: caetanofdm@hotmail.com

${ }^{2}$ Doutora em Ciências. Docente EBTT, tutora PET/MEC, Instituto Federal de Educação, Ciência e

Tecnologia do Rio Grande do Sul. E-mail: cibele.schwanke@ poa.ifrs.edu.br
} 


\section{Resumen}

Hemos llegado a un punto crítico en relación con el uso de los activos naturales, donde la contaminación del aire, agua y tierra ha causado degradación de la calidad del aire, escasez de agua, infertilidad del suelo e injusticias sociales. En vista de este escenario, la gestión ambiental, la percepción ambiental y las acciones de educación ambiental se destacan para remediar este contexto. Este artículo presenta los resultados de una investigación cualitativa, realizada en base al desarrollo de acciones de educación ambiental en una comunidad en riesgo y en vulnerabilidad socioambiental. El diagnóstico de cómo los niños que participan en un proyecto perciben la naturaleza, antes y después de las acciones de educación ambiental implementadas, se llevó a cabo en un intento por comprender los cambios que ocurrieron en sus relaciones con su espacio y naturaleza. En vista del público compuesto por niños de seis a ocho años, se utilizaron dibujos, que luego se interpretaron mediante análisis de contenido. Como resultado de la intervención, se identificó que los estudiantes comenzaron a percibirse a sí mismos como parte de la naturaleza y los agentes que actúan en sus espacios y que la relación y la percepción ambiental de los estudiantes cambiaron, pasando de una percepción ambiental fuera de contexto con la realidad, a una percepción gestión ambiental contextualizada y participativa.

Palabras clave: Educación ambiental. Gestión ambiental. Dibujo. Naturaleza.

\section{Introdução}

Chegamos a um ponto crítico com relação ao uso dos bens naturais, onde a poluição do ar, da água e da terra têm causado degradação na qualidade do ar, escassez de água, infertilidade dos solos e injustiças sociais. Resultado do capitalismo industrial, que teve início na Revolução Industrial na Grã-Bretanha, esse modelo tem como foco a produção em massa e o crescimento econômico. Iniciado no século XVIII, trouxe mudanças econômicas e sociais com a evolução dos processos produtivos e uma nova concepção entre o trabalho humano e as máquinas (REGO, 2013, p.15). Marcada pela superexploração dos recursos naturais e sociais, Carvalho (2009, p.141) destaca que "a indústria nascente chega triunfante, trazendo, contudo, sua inexorável contra face: a degradação ambiental e a exploração da força de trabalho". A Revolução Industrial também causou impactos no meio rural com a Revolução Verde, estruturada a partir dos anos de 1960, tendo como base a mecanização do campo, o uso de insumos derivados do petróleo, a monocultura, o monopólio de tecnologias, o uso intensivo do solo, a supervalorização do capital, a promessa de aumento da produtividade e o êxodo rural (MAZOYER; ROUDART, 2010).

Tais mudanças aprofundaram a desigualdade social e a degradação ambiental, onde o ônus de um meio ambiente desequilibrado e degradado é direcionado, principalmente, aos excluídos socialmente. A questão ambiental ganhou destaque nas principais conferências mundiais, onde a I Conferência das Nações Unidas sobre o Meio Ambiente, também conhecida como conferência de Estocolmo - Suécia 1972, oficializou a preocupação com o meio ambiente e a necessidade de implementação de políticas globais, visando a preservação e a conservação do meio ambiente e a melhoria ambiental (SCHWANKE; CADEI, 2013). A II Conferência das Nações Unidas para o Meio Ambiente e o Desenvolvimento, conhecida como Rio-92 ou Eco-92, tornou-se referência mundial à construção de acordos ambientais internacionais, dando origem a vários documentos, dentre os quais se destaca a Carta da Terra, que após oito anos de discussões foi aprovada no ano de 2000, sua elaboração envolveu 46 países e mais de cem mil pessoas, sendo assumida como documento oficial pela UNESCO, em 2002. Esse documento expressa que:

Os padrões dominantes de produção e consumo estão causando devastação ambiental, redução dos recursos e uma massiva extinção de espécies. Comunidades estão sendo arruinadas. Os benefícios do desenvolvimento não estão sendo divididos equitativamente e o fosso entre ricos e pobres está aumentando (UNESCO, 2002, p. 126). 
Nesse cenário, e considerando que poucos se utilizam das riquezas geradas com a destruição do meio ambiente, mas as consequências da destruição impactam a maioria das vidas, percebe-se que os benefícios são para poucos e os malefícios, no entanto, são para a maioria. De acordo com o relatório Recompensem o trabalho, não a riqueza (OXFAM, 2018), de toda a riqueza gerada no mundo em 2017, $82 \%$ foi parar nas mãos de $1 \%$ da população do planeta. Enquanto isso, a metade mais pobre da população global - 3,7 bilhões de pessoas - vive em situação de vulnerabilidade social, demonstrando, assim, a desigualdade social que nos rodeia.

Considerando a amplitude do meio ambiente enquanto um conjunto de condições, leis, influências e interações de ordem física, química, biológica, social, cultural e urbanística, que permite, abriga e rege a vida em todas as suas formas (Art $3^{\circ}$, Inciso I, da Política Nacional do Meio Ambiente, Lei nº 6.938 (BRASIL, 1981)), em situações de crise ambiental, o que não percebemos são as interações entre os constituintes do meio ambiente, os físicos, químicos, biológicos, sociais, culturais e urbanísticos, e o quanto cada constituinte é impactado. Para enfrentar a crise ambiental que nos é imposta, devemos ter consciência da integralidade do meio ambiente e de todos os seus constituintes, incluindo a espécie humana. Como destacado por Santos (2005, p. 141): “o que hoje se chama agravos ao meio ambiente na realidade não são outra coisa senão agravos ao meio de vida do ser humano, isto é, ao meio visto em sua integralidade".

Uma questão central para o entendimento da crise ambiental e de como enfrentá-la consiste em estabelecer como o ser humano percebe o meio ambiente. A percepção ambiental pode ser entendida pelo modo como os indivíduos veem, compreendem e se comunicam com o ambiente, considerando, também, as influências ideológicas de cada sociedade (ROSA, 2002 apud VILLAR et al., 2008). A percepção ambiental caracteriza a forma como o sujeito se relaciona com o meio em que está inserido. Ao inserir-se como parte do meio, passa a estabelecer outra relação com os constituintes do meio ambiente, tendo a consciência de que é responsável e capaz de transformar a sua realidade. Segundo Palma (2005):

\footnotetext{
Entende-se por percepção a interação do indivíduo com seu meio. Este envolvimento dá-se através dos órgãos do sentido. Para que possamos realmente PERCEBER, é necessário que tenhamos algum interesse no objeto de percepção e esse interesse é baseado nos conhecimentos, na cultura, na ética, e na postura de cada um, fazendo com que cada pessoa tenha uma percepção diferenciada para o mesmo objeto (PALMA, 2005, p. 16, grifo do autor).
}

O interesse para que os sujeitos efetivamente possam perceber o meio, destacado por Palma (2005), pode emergir de diversas formas. Nesse contexto, ações de sensibilização são fundamentais para que a percepção efetive-se em tomada de consciência, uma vez que:

A ação de conscientização pressupõe a necessidade de sensibilizar o público sobre os problemas de meio ambiente e desenvolvimento, fazê-lo participar de suas soluções e fomentar o senso de responsabilidade pessoal em relação ao meio ambiente, com maior motivação e dedicação em relação ao desenvolvimento sustentável (BEHLING; GIL; CARLAN, 2015, p. 20).

Por conseguinte, o estudo da percepção ambiental é essencial para o planejamento de ações de educação ambiental, pois esse entendimento direciona as ações de intervenção para $\mathrm{o}$ atendimento às fragilidades e às potencialidades identificadas pelo estudo (PEDRINI; COSTA; GHILARDI, 2010). Também, se configura em uma importante ferramenta para verificar as mudanças que foram alcançadas (ou não) com as ações de educação ambiental. Portanto, é fundamental compreender como os sujeitos percebem e representam o ambiente 
em que vivem, tornando o processo educativo mais proveitoso (SIMMONS, 1994 apud SILVA, 2017).

Através da educação ambiental (EA) é possível mudar a forma como o sujeito percebe a natureza, fazendo com que se identifique como parte do meio ambiente e, além disso, enxergue o meio ambiente como algo integrado e sistêmico, onde os seus constituintes interagem e se influenciam, percebendo que as suas ações impactam no meio ambiente e que um meio ambiente impactado influencia as diversas dimensões da sua vida. Segundo Loureiro (2002), a EA é uma práxis educativa e social que tem por finalidade a construção de valores, conceitos, habilidades e atitudes que possibilitam o entendimento da realidade de vida e a atuação lúcida e responsável de atores sociais individuais e coletivos no ambiente.

A partir dessa mudança de percepção, o sujeito adquire a base para contribuir com a mudança da sua realidade, considerando que a sua realidade diz respeito às interações meio ambiente e seres humanos, de forma integrada e sistêmica. O que aconteceria através de uma mudança de postura que busca despertar o sujeito para os problemas ambientais, suas causas e consequências, objetivando a ação crítica (GUIMARÃES, 2004); também, através de uma postura emancipatória - que preconiza as noções de mudança social e cultural, de emancipação e libertação individual e social e de integração, incluindo questões políticas à problemática ambiental (QUINTAS, 2004), e de uma postura transformadora - que, por sua vez, promove a articulação dos sujeitos envolvidos no problema, em busca do questionamento dos modelos tradicionais de desenvolvimento visando a transformação da sociedade (LOUREIRO, 2004).

A gestão ambiental se utiliza da EA e do estudo de percepção ambiental para planejar e executar ações de intervenção socioambiental, buscando, assim, uma relação mais equitativa com o meio ambiente, dando subsídios para que os atores sociais mais vulneráveis possam ter condições de intervir, de forma positiva, no seu meio ambiente, Quintas (2005) destaca que a gestão ambiental:

É um processo de mediação de interesses e conflitos entre atores sociais que agem sobre os meios físico natural e construído. Este processo de mediação define e redefine, continuamente, o modo como os diferentes atores sociais, através de suas práticas, alteram a qualidade do meio ambiente e também como se distribuem na sociedade os custos e os benefícios decorrentes da ação destes agentes. (QUINTAS, 2005, p. 125).

Nas grandes cidades, é possível observar regiões desenvolvidas no centro e regiões subdesenvolvidas na periferia, que são as mais atingidas pelos riscos ambientais, resultando em situações de vulnerabilidade socioambiental, caracterizada pela:

Coexistência ou sobreposição espacial entre grupos populacionais muito pobres e com alta privação (vulnerabilidade social) e áreas de risco ou degradação ambiental (vulnerabilidade ambiental). Neste sentido, é justamente a combinação destas duas dimensões que está sendo considerada uma situação de vulnerabilidade socioambiental (ALVES, 2006, p. 43 - 44).

Devido à urbanização e à especulação imobiliária, os espaços menos suscetíveis aos riscos ambientais foram supervalorizados e as áreas mais suscetíveis aos riscos ambientais foram menosprezadas, criando, assim, uma segregação espacial nas cidades, que coloca populações em risco. Nesse sentido, entende-se que o risco ambiental:

Pode ser considerado como a contingência de acontecimentos como: deslizamentos, enchentes/inundações, as diversas formas de contaminação, seja por via atmosférica ou hídrica, ou ainda as decorrentes do contato com o lixo, entre outras. A possibilidade de perdas, que é inerente ao risco, incluído aí o ambiental, 
possui uma dimensão espacial. Assim, um evento desastroso pode resultar em danos materiais, doenças e até perda de vidas humanas em sua área de ocorrência (ESTEVES, 2011, p. 69).

Esse cenário é resultado de uma exclusão social e ambiental, na qual mais pobres são os mais afetados pelos riscos de um meio ambiente degradado e estão sujeitos às consequências dos impactos causados por um modelo de desenvolvimento predatório e consumista como, por exemplo, enchentes, doenças, violência, baixa expectativa de vida, baixa qualidade de vida, desemprego, supressão de direitos.

Levando em consideração o cenário da crise ambiental, do papel da gestão ambiental e da importância da educação e percepção ambiental, foi desenvolvido um projeto de educação ambiental na Zona Sul de Porto Alegre (Rio Grande do Sul), em uma comunidade que vive em situação de vulnerabilidade socioambiental. Nesse território vivem 554 famílias que habitam as margens do Arroio Cavalhada, que atravessa o Bairro Cristal (Figura 1).

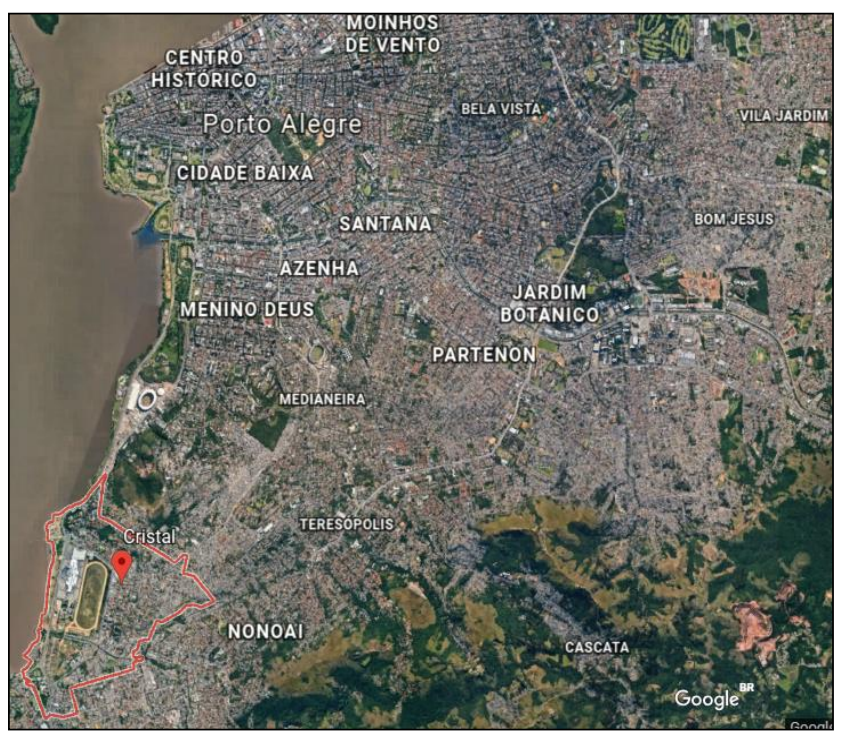

Figura 1 - localização do Bairro Cristal no município de Porto Alegre Fonte: Google Maps (2018)

Essas comunidades possuem um extremo grau de carência, apresentando condições precárias de moradia (tanto no que se refere ao local de risco, quanto às condições de habitabilidade) e de vida, residindo em ocupações irregulares, sem padronização na sua construção e nos espaços de circulação, caracterizando-se por becos e acessos estreitos, além de casas muito próximas umas das outras, ou até mesmo, conjugadas de forma rudimentar. Não há calçamentos, nem pavimentação. $\mathrm{O}$ acesso ao abastecimento de água e energia elétrica é, em sua maioria, irregular, bem como, o esgoto, em alguns casos, encontra-se sem tratamento, a céu aberto, despejado diretamente no arroio. O descarte do lixo das famílias é realizado de maneira inadequada. Percebe-se que tanto resíduos domiciliares, quanto objetos em desuso, tais como mobiliários, acumulam-se nos espaços da comunidade, além de serem despejados no arroio. Há espaços livres que são utilizados por terceiros para depósito de dejetos e materiais, além de moradores que recebem pagamento para desocupar resíduos de outras regiões, trazendo-os para as comunidades em que vivem, como, por exemplo, carroceiros. Ainda em relação ao lixo, há pessoas que trabalham com reciclagem e acumulam materiais em suas residências. Essas características, acrescidas da proximidade com o Arroio Cavalhada, permitem que, em ocasiões de chuvas, lixos e outros materiais se tornem fator de represamento, facilitando enchentes e alagamentos nas comunidades e vias de acesso no entorno. 
O projeto que é o foco deste artigo foi desenvolvido por um grupo de graduandos, liderados por um tutor de uma instituição de ensino superior que atua há oito anos com ações de educação ambiental, levando em consideração os eixos do ensino, pesquisa e extensão, em parceria com uma organização assistencial que presta serviços de assistência social na comunidade e, também, com o Projeto Integrado Socioambiental (PISA) da Prefeitura Municipal de Porto Alegre, que tem como objetivo aumentar a capacidade de tratamento de esgoto do município, a recuperação de arroios e a remoção de famílias em situação de risco.

O projeto, baseado na indissociabilidade entre pesquisa-ensino-extensão foi aprovado para execução pela IES e contou com fomento do Programa de Educação Tutorial do Ministério da Educação. Mediante as ações de educação ambiental realizadas na unidade assistencial, ampliou o alcance de suas atividades, buscando outros espaços. Além das dependências como as salas de aula, promoveu-se a construção de um espaço integrado de educação ambiental, constituído por cisterna, composteira e hortas em um local da comunidade que, anteriormente, servia como depósito de resíduos, objetivando uma mudança na forma como os sujeitos percebem e se relacionam com o meio ambiente e seus espaços.

O público do projeto, realizado ao longo do ano de 2017, foi constituído por uma turma de quinze crianças, com idades entre seis e oito anos, essa turma faz parte de uma instituição sem fins lucrativos que presta serviços sociais para crianças da comunidade, oferendo apoio pedagógico e cultural em turno inverso ao da escola. A proposta teve sua aprovação pelo conselho gestor da unidade assistencial, o consentimento dos responsáveis e assentimento dos participantes. Tendo em vista a faixa etária das crianças, utilizou-se desenhos para realizar o diagnóstico de percepção ambiental. Tal escolha foi considerada por entender que a faixa etária na qual as crianças se apresentam representa a terceira etapa do desenvolvimento do desenho infantil, que se inicia por volta dos sete anos e se estende até os nove anos. Nesta etapa, chamada de Estágio Esquemático, a criança já desenvolveu o conceito de forma e seus desenhos são representativos, descritivos e organizados, representando partes de si e do seu meio (LOWENFELD; BRITTAIN, 1977 apud BARBOSA, 2013).

Além disso, considerou-se que os desenhos infantis, muitas vezes, passam despercebidos como manifestações expressivas e representativas das características sociais, históricas, culturais e econômicas de seus criadores (GOBBI, 2014). Nesse aspecto, Tamaio (2000), que desenvolveu um trabalho utilizando desenhos para analisar a mudança de percepção ambiental em crianças, destaca que:

\footnotetext{
A produção do desenho implica em um movimento interpretativo que é inseparável da linguagem. $\mathrm{O}$ conhecimento possibilita que a criança faça um registro do que ela conhece e conceitua em sua realidade. Nesse sentido, os desenhos representam uma possibilidade de expressão (urna nova linguagem) que eu nunca havia utilizado nas minhas práticas pedagógicas. No decorrer do processo de aprendizagem, essa mostrou ser uma das formas mais desejadas pelos alunos para simbolizar o real (TAMAIO, 2000, p. 33).
}

Tendo em vista esse contexto, o presente artigo apresenta um diagnóstico, através da análise de desenhos, sobre como as crianças participantes do projeto percebem a natureza, antes e depois das ações de educação ambiental implementadas, na tentativa de compreender se houve, ou não, mudanças significativas em suas relações com o seu espaço e a natureza.

\section{Construindo uma mudança de percepção ambiental: um projeto de educação ambiental}


Quando se fala em meio ambiente, a ideia que predomina é de um ideal naturalista, de uma natureza intocada, sem a presença humana e como algo distante. Carvalho (2017) destaca que esse imaginário se baseia, principalmente, na percepção da natureza como sendo um fenômeno estritamente biológico e autônomo, reforçando o entendimento de que há um mundo natural constituído em oposição ao mundo humano. Essa visão limitada do meio ambiente reduz a possibilidade de interações entre os constituintes sociais, biológicos, físicos, políticos e ambientais, pois não considera o meio ambiente de forma sistêmica e integrada, o que leva à redução do meio ambiente a apenas uma de suas dimensões, desprezando a riqueza da permanente interação entre natureza e a cultura humana.

A educação ambiental, a partir de uma visão socioambiental, busca superar essa visão limitada do meio ambiente, considerando as suas interações, pois:

A visão socioambiental orienta-se por uma racionalidade complexa e interdisciplinar e pensa o meio ambiente não como sinônimo de natureza intocada, mas como um campo de interações entre a cultura, a sociedade e a base física e biológica dos processos vitais, no qual todos os termos dessa relação se modificam dinamicamente (CARVALHO, 2017, p. 37).

Partindo desse enfoque, através da educação ambiental, o projeto teve como objetivo provocar um princípio de transformação na percepção ambiental dos educandos, buscando, assim, uma mudança na forma como os sujeitos interagem com o meio ambiente. As ações de intervenção ocorreram ao longo do ano de 2017, em encontros semanais, sendo que nos meses de janeiro, fevereiro e março foram realizados os contatos com a instituição, identificação dos espaços e estratégias para viabilizar a organização de espaços educativos, levantamento de demandas e possibilidades e, por fim, o planejamento das ações a serem implementadas.

Considerando o contexto social, a intencionalidade na continuidade das ações na comunidade para além do período de execução do projeto e, na tentativa de contribuir para a superação da visão limitada do meio ambiente, utilizou-se pressupostos pautados na pedagogia da práxis, que preconiza uma educação transformadora. Ela se baseia numa visão antropológica que considera o ser humano um ser incompleto, inconcluso e inacabado e, por isso, um ser criador, sujeito da história, que se transforma na medida em que provoca transformações no mundo (GADOTTI, 2005).

Somando-se a isso, reconheceu-se que uma prática baseada na pedagogia dos contextos de aprendizagem poderia, também, contribuir para que os sujeitos envolvidos realizassem uma leitura crítica do seu mundo, não representada, apenas, pela "palavra escrita ou da linguagem escrita, mas que se antecipa e se alonga na inteligência do mundo" (FREIRE, 1992, p. 11).

Nesse sentido, como destacado por Tristão e Fassarella (2007), os contextos de aprendizagem representam não apenas salas de aula, mas, também, múltiplos espaços e tempos de vidas articulados com a produção de saberes voltados para a formação de diferentes sujeitos ativos na Educação Ambiental. Como destacado por Figueiredo (2016, p. 813), "um contexto de aprendizagem é um conjunto coerente de fatos, circunstâncias e pessoas que acompanham e concretizam uma situação de aprendizagem". Nessa concepção, educadores e educandos da ONG parceira e a equipe executora do projeto, composta por professores e discentes, constituíram-se em um grupo intencionalmente envolvido. Entendese que a formação de uma equipe multidisciplinar e interinstitucional foi fundamental para minimizar as limitações da prática da educação ambiental na educação infantil, que, como destacado por Luccas e Bonotto (2017), é realizada, muitas vezes, de forma pontual, devido à carência na formação dos educadores e de materiais pedagógicos. Somando-se a isso, uma equipe representada por vários atores sociais, tendo como foco o trabalho dos educadores em 
uma concepção mais ampla e coletiva, possibilitou o planejamento de ações e situações de estudo inter-relacionadas, o que vem demonstrando resultados favoráveis no contexto da educação infantil (UHMANN; VORPAGEL, 2018).

A prática da educação ambiental possibilita o desenvolvimento de ações organizadas a partir de diversas concepções, que pressupõem estratégias diversificadas e que utilizam diversas abordagens, baseadas nas correntes de educação ambiental. De acordo com Sauvé (2005), a noção de corrente refere-se, aqui, a uma maneira geral de conceber e de praticar a educação ambiental. Embora cada uma das correntes apresente um conjunto de características específicas que a distingue das outras, elas não são mutuamente excludentes, podendo ser praticadas em conjunto, complementando-se entre si (SAUVÉ, 2005).

Nesse caminho, Sato (2001), em uma abordagem que analisa diferentes formas e possibilidades de intervenções, demonstra que as ações de educação ambiental não podem ser limitadas por uma determinada visão e nem limitantes em suas práticas.

Dessa forma, na construção e concepção das atividades desenvolvidas as principais correntes utilizadas foram: científica, moral/ética, conservacionista/recursista, naturalista, projeto de desenvolvimento sustentável, humanista e ecoeducação e, em alguns momentos, algumas atividades contemplavam mais de um tipo de corrente. Os Quadros 1 e 2 apresentam cada atividade realizada ao longo do projeto, caracterizando-a em sua concepção, incluindo a descrição da atividade, objetivos e corrente da educação ambiental (baseada em SAUVÉ, 2005). Nesse âmbito, ressalta-se que as práticas educativas foram pensadas de forma a trabalhar múltiplas dimensões formativas e contemplar diferentes saberes, envolvendo conhecimentos científicos, vivências corporais e sensoriais, atividades lúdicas, domínio de técnicas e atividades de pintura, entre outros.

\begin{tabular}{|c|c|c|c|}
\hline Atividade & Descrição & Objetivo da atividade & Corrente da EA \\
\hline $\begin{array}{l}\text { Aplicação de } \\
\text { instrumento } \\
\text { diagnóstico }\end{array}$ & $\begin{array}{c}\text { Desenho livre, solicitando que as } \\
\text { crianças representem o que é } \\
\text { natureza, no primeiro dia de } \\
\text { atividade }\end{array}$ & $\begin{array}{c}\text { Analisar como o público percebe a } \\
\text { natureza, a fim de definir a melhor } \\
\text { forma de abordagem das ações; } \\
\text { possuir um referencial comparativo, } \\
\text { para avaliar se houve alguma } \\
\text { mudança na percepção ambiental } \\
\text { após o desenvolvimento das } \\
\text { atividades. }\end{array}$ & Não se aplica \\
\hline $\begin{array}{l}\text { Plantando } \\
\text { sementes }\end{array}$ & $\begin{array}{l}\text { Plantar sementes de rápido } \\
\text { crescimento, como milho, painço, } \\
\text { alpiste }\end{array}$ & $\begin{array}{l}\text { Observar o desenvolvimento de } \\
\text { plantas, aprender a cultivar uma } \\
\text { semente, despertar o senso de } \\
\text { responsabilidade e trabalhar a } \\
\text { paciência }\end{array}$ & $\begin{array}{l}\text { Corrente } \\
\text { científica }\end{array}$ \\
\hline $\begin{array}{c}\text { Filme } \\
\text { educativo }\end{array}$ & $\begin{array}{l}\text { Exibição do filme “O Lorax: Em } \\
\text { Busca da Trúfula Perdida", que faz } \\
\text { uma crítica ao consumismo e à forma } \\
\text { destrutiva de se relacionar com as } \\
\text { pessoas e com o meio ambiente }\end{array}$ & $\begin{array}{c}\text { Estimular o público-alvo com filmes } \\
\text { educativos sobre questões ambientais } \\
\text { atuais e refletir sobre o atual modelo } \\
\text { de consumo }\end{array}$ & $\begin{array}{c}\text { Corrente } \\
\text { moral/ética }\end{array}$ \\
\hline $\begin{array}{l}\text { Importância } \\
\text { das árvores }\end{array}$ & $\begin{array}{c}\text { Atividade da caixa-preta. } \\
\text { Identificação se o elemento retirado } \\
\text { da caixa é necessário para o } \\
\text { desenvolvimento das árvores. Após, } \\
\text { em grupos, as crianças representam o } \\
\text { aprendizado em forma de desenho }\end{array}$ & $\begin{array}{l}\text { Demonstrar, de forma lúdica, a } \\
\text { importância das árvores, estimulando } \\
\text { o trabalho em grupo }\end{array}$ & $\begin{array}{c}\text { Corrente } \\
\text { conservacionista } \\
/ \\
\text { recursista }\end{array}$ \\
\hline $\begin{array}{c}\text { Vivência na } \\
\text { natureza }\end{array}$ & $\begin{array}{l}\text { Caça ao tesouro no pátio da ONG. } \\
\text { Busca por elementos da natureza e } \\
\text { coisas com que as crianças se }\end{array}$ & $\begin{array}{l}\text { Desenvolver a percepção, observação } \\
\text { e identificação do ambiente, } \\
\text { destacando que elas fazem parte do }\end{array}$ & $\begin{array}{c}\text { Corrente } \\
\text { naturalista }\end{array}$ \\
\hline
\end{tabular}




\begin{tabular}{|c|c|c|c|}
\hline & identifiquem & $\begin{array}{l}\text { mesmo; destacar a importância de } \\
\text { todos os constituintes da natureza e } \\
\text { também as suas interações }\end{array}$ & \\
\hline $\begin{array}{c}\text { Alusiva ao dia } \\
\text { das mães }\end{array}$ & $\begin{array}{l}\text { Confecção de cartão e uma flor } \\
\text { utilizando tintas à base de corantes } \\
\text { naturais (beterraba, açafrão da terra, } \\
\text { colorau) }\end{array}$ & $\begin{array}{l}\text { Momento lúdico, relacionando } \\
\text { materiais recicláveis e naturais com a } \\
\text { temática do dia das mães, destacando } \\
\text { o impacto das tintas convencionais e } \\
\text { tóxicas para o meio ambiente e para } \\
\text { as pessoas }\end{array}$ & $\begin{array}{c}\text { Projeto de } \\
\text { desenvolvimento } \\
\text { sustentável }\end{array}$ \\
\hline $\begin{array}{l}\text { Roda de } \\
\text { conversa e } \\
\text { desenho }\end{array}$ & $\begin{array}{l}\text { Foi realizada uma roda de conversa } \\
\text { onde foi perguntado para as crianças } \\
\text { o que elas desejavam cultivar na horta } \\
\text { e, em seguida, foi feito um desenho de } \\
\text { como elas imaginavam que seria o } \\
\text { espaço da horta }\end{array}$ & $\begin{array}{l}\text { Incluir as crianças no processo de } \\
\text { planejamento da horta, iniciar o } \\
\text { processo de cultivo das mudas da } \\
\text { horta, destacar o protagonismo dos } \\
\text { atores sociais na transformação da sua } \\
\text { realidade e incentivar a imaginação }\end{array}$ & $\begin{array}{c}\text { Corrente } \\
\text { humanista }\end{array}$ \\
\hline $\begin{array}{l}\text { Se } \\
\text { conhecendo e } \\
\text { conhecendo } \\
\text { os outros } \\
\text { melhor }\end{array}$ & $\begin{array}{l}\text { Com o grupo organizado numa roda e } \\
\text { uma música tocando, pegue um balão } \\
\text { e vá passando de mão em mão, } \\
\text { quando a música parar quem estiver } \\
\text { com o balão terá que responder a uma } \\
\text { pergunta. Pode ser uma pergunta } \\
\text { relacionada com o meio ambiente, } \\
\text { com a horta, com algo do cotidiano }\end{array}$ & $\begin{array}{l}\text { Trabalhar o respeito com a pessoa que } \\
\text { está com a palavra, conhecer um ao } \\
\text { outro, desenvolver uma relação de } \\
\text { confiança entre as pessoas, trabalhar a } \\
\text { coordenação motora e a atenção }\end{array}$ & $\begin{array}{c}\text { Corrente da } \\
\text { ecoeducação }\end{array}$ \\
\hline $\begin{array}{c}\text { Degustação } \\
\text { de frutas }\end{array}$ & $\begin{array}{l}\text { Essa atividade consiste em trabalhar } \\
\text { com as crianças a importância das } \\
\text { frutas e estabelecer um vínculo e } \\
\text { conhecimento das plantas a partir da } \\
\text { experimentação de frutas. Com os } \\
\text { olhos vendados, as crianças devem } \\
\text { experimentar as frutas e depois } \\
\text { responder qual fruta está } \\
\text { experimentando; no final da atividade } \\
\text { fornecer uma salada de frutas com } \\
\text { todas as frutas. }\end{array}$ & $\begin{array}{l}\text { A atividade tem como objetivo } \\
\text { principal estimular as crianças através } \\
\text { de uma vivência lúdica e } \\
\text { experimental a conhecer as frutas que } \\
\text { elas comem e todo o seu ciclo natural, } \\
\text { bem como estimular e promover a } \\
\text { alimentação saudável. }\end{array}$ & $\begin{array}{l}\text { Corrente da } \\
\text { ecoeducação }\end{array}$ \\
\hline $\begin{array}{c}\text { Decorando a } \\
\text { horta }\end{array}$ & $\begin{array}{l}\text { Confecção de flores decorativas feitas } \\
\text { de garrafa pet (fundo da garrafa) junto } \\
\text { com os educadores da ONG para a } \\
\text { horta. As garrafas serão cortadas para } \\
\text { que, junto com os professores, os } \\
\text { alunos as pintem e decorem. }\end{array}$ & $\begin{array}{l}\text { Envolver educadores e educandos na } \\
\text { construção/decoração da horta } \\
\text { comunitária da Casa de Nazaré, } \\
\text { trazendo conceitos de reciclagem de } \\
\text { resíduos de garrafa pet. }\end{array}$ & $\begin{array}{c}\text { Corrente } \\
\text { humanista/ } \\
\text { Projeto de } \\
\text { desenvolvimento } \\
\text { sustentável }\end{array}$ \\
\hline $\begin{array}{l}\text { Encerramento } \\
\text { do primeiro } \\
\text { semestre de } \\
2017\end{array}$ & $\begin{array}{l}\text { Foram plantadas sementes nos } \\
\text { canteiros, a fim de mostrar a forma de } \\
\text { cultivo direto. }\end{array}$ & $\begin{array}{l}\text { Realizar uma atividade onde fosse } \\
\text { possível as crianças observarem as } \\
\text { diferenças antes e depois das férias na } \\
\text { horta, conhecer outras formas } \\
\text { cultivos e visualizar o ciclo da } \\
\text { natureza. }\end{array}$ & $\begin{array}{c}\text { Corrente da } \\
\text { ecoeducação }\end{array}$ \\
\hline
\end{tabular}

Quadro 1 - atividades desenvolvidas no primeiro semestre de execução do projeto de EA Fonte: dados da pesquisa (2018)

\begin{tabular}{|c|c|c|c|}
\hline Atividade & Descrição & Objetivo da atividade & Corrente da EA \\
\hline Jardim suspenso & $\begin{array}{l}\text { Confecção de uma horta suspensa } \\
\text { utilizando garrafas PET, com plantio } \\
\text { de pelas crianças }\end{array}$ & $\begin{array}{l}\text { Mostrar as diferentes formas de } \\
\text { cultivo e incluir as crianças na } \\
\text { construção do espaço da horta, } \\
\text { criando assim um sentimento de } \\
\text { pertencimento }\end{array}$ & $\begin{array}{l}\text { Corrente da } \\
\text { ecoeducação }\end{array}$ \\
\hline
\end{tabular}




\begin{tabular}{|c|c|c|c|}
\hline $\begin{array}{l}\text { Ciclo da água e } \\
\text { seu consumo } \\
\text { consciente }\end{array}$ & $\begin{array}{l}\text { A partir do vídeo 'O Show da Luna! } \\
\text { Como a Água Vira Chuva?', } \\
\text { contextualizar o ciclo da água, } \\
\text { realizando uma reflexão coletiva. } \\
\text { Visita ao espaço, explicando o } \\
\text { funcionamento da cisterna e alertá- } \\
\text { los sobre o uso consciente da água. } \\
\text { Por fim, roda de conversa, utilizando } \\
\text { copos de } 200 \mathrm{ml} \text { de água com os quais } \\
\text { lavarão as mãos em um recipiente } \\
\text { compartilhado, reutilizando a água } \\
\text { para regar os canteiros. }\end{array}$ & $\begin{array}{c}\text { Conhecer o ciclo da água e sua } \\
\text { importância para a manutenção dos } \\
\text { ecossistemas }\end{array}$ & $\begin{array}{l}\text { Corrente } \\
\text { conservacionista } \\
\text { / } \\
\text { recursista }\end{array}$ \\
\hline $\begin{array}{l}\text { Resíduos e suas } \\
\text { classificações }\end{array}$ & $\begin{array}{l}\text { Confeccionar } 5 \text { placas com o texto: } \\
\text { papel, metal, plástico, vidro e } \\
\text { orgânico e escrever } 5 \text { resíduos de } \\
\text { cada tipo. Fixar as placas chamando } \\
\text { um aluno para retirar um papel e } \\
\text { perguntar a todos em qual categoria } \\
\text { de resíduo se encaixa. Repetir até } \\
\text { todos educandos participarem. }\end{array}$ & $\begin{array}{l}\text { Conhecer os tipos de resíduos e a } \\
\text { importância da correta separação } \\
\text { relacionando com a composteira, a } \\
\text { reciclagem de matéria prima e a } \\
\text { reciclagem de nutrientes. Destacar } \\
\text { a redução de resíduos destinados } \\
\text { para o aterro sanitário. }\end{array}$ & $\begin{array}{c}\text { Corrente } \\
\text { conservacionista } \\
/ \\
\text { recursista }\end{array}$ \\
\hline $\begin{array}{l}\text { Preparação das } \\
\text { mudas }\end{array}$ & $\begin{array}{l}\text { As mudas foram preparadas em } \\
\text { caixas de ovos, onde as crianças } \\
\text { plantaram as sementes e observaram } \\
\text { o crescimento das mudas, para depois } \\
\text { plantar as mudas na horta. Foi } \\
\text { proposto que, juntamente com o } \\
\text { educador, as crianças } \\
\text { acompanhassem o crescimento das } \\
\text { mudas e anotassem num mural. }\end{array}$ & $\begin{array}{c}\text { Preparar as mudas, observar o ciclo } \\
\text { da horta/natureza e incluir o } \\
\text { educador da ONG nas atividades } \\
\text { de EA. }\end{array}$ & $\begin{array}{l}\text { Corrente } \\
\text { científica }\end{array}$ \\
\hline $\begin{array}{l}\text { Trabalhando a } \\
\text { composteira }\end{array}$ & $\begin{array}{l}\text { Consumir frutas com as crianças e } \\
\text { após depositar na composteira, } \\
\text { explicando o ciclo dos nutrientes, } \\
\text { destacando que após o consumo de } \\
\text { frutas as cascas servirão para cultivar } \\
\text { novos alimentos }\end{array}$ & $\begin{array}{l}\text { Mostrar a importância da } \\
\text { destinação correta dos resíduos } \\
\text { orgânicos, conhecer o ciclo da } \\
\text { matéria orgânica e como ocorre a } \\
\text { interação com a horta contribuindo } \\
\text { para o crescimento das plantas }\end{array}$ & $\begin{array}{c}\text { Corrente } \\
\text { conservacionista } \\
/ / \\
\text { recursista }\end{array}$ \\
\hline $\begin{array}{l}\text { Plantando } \\
\text { mudas }\end{array}$ & $\begin{array}{l}\text { Plantar as mudas cultivadas pelas } \\
\text { crianças no espaço da horta, } \\
\text { integrando os constituintes presentes } \\
\text { no espaço, utilizando o composto da } \\
\text { composteira, a água da cisterna e os } \\
\text { canteiros construídos, mostrando } \\
\text { como o meio ambiente funciona de } \\
\text { forma integrada e sistêmica. }\end{array}$ & $\begin{array}{l}\text { Unir os conhecimentos adquiridos } \\
\text { durante o ano e mostrar como o } \\
\text { meio ambiente funciona de forma } \\
\text { integrada e sistêmica }\end{array}$ & $\begin{array}{l}\text { Corrente } \\
\text { naturalista/ } \\
\text { Corrente da } \\
\text { ecoeducação }\end{array}$ \\
\hline $\begin{array}{c}\text { Plantando } \\
\text { girassóis e } \\
\text { cuidados com a } \\
\text { horta }\end{array}$ & $\begin{array}{l}\text { Plantar sementes de girassol e } \\
\text { explicar os cuidados com a horta. }\end{array}$ & $\begin{array}{c}\text { Cultivar espécies decorativas e } \\
\text { mostrar a importância dos cuidados } \\
\text { com a horta. }\end{array}$ & $\begin{array}{l}\text { Corrente da } \\
\text { ecoeducação }\end{array}$ \\
\hline $\begin{array}{l}\text { Atividade de } \\
\text { encerramento } \\
\text { do projeto }\end{array}$ & $\begin{array}{l}\text { Construção de mosaico de tampinhas } \\
\text { com a descrição "horta", } \\
\text { "composteira", "água” e um coração. } \\
\text { Entrega simbólica do espaço aos } \\
\text { coordenadores, educadores e } \\
\text { educandos. Fixação de Banners de } \\
\text { EA sobre água, energia elétrica, horta } \\
\text { e resíduos. }\end{array}$ & $\begin{array}{l}\text { Personalizar a horta, criando um } \\
\text { sentimento de pertencimento e } \\
\text { incluir as crianças na construção do } \\
\text { espaço da horta. Entregar material } \\
\text { visando continuidade das ações aos } \\
\text { educadores da ONG. }\end{array}$ & $\begin{array}{l}\text { Corrente da } \\
\text { ecoeducação }\end{array}$ \\
\hline Aplicação de & Aplicar desenho livre e pedir para & A atividade teve como foco fazer a & \\
\hline
\end{tabular}




\begin{tabular}{|c|c|c|}
\hline $\begin{array}{l}\text { instrumento de } \\
\text { diagnóstico }\end{array}$ & $\begin{array}{c}\text { que as crianças representem o que é } \\
\text { a natureza para eles, no primeiro dia } \\
\text { de atividade }\end{array}$ & $\begin{array}{l}\text { análise de como o público alvo } \\
\text { percebe a natureza, a fim de avaliar } \\
\text { se houve alguma mudança ou não } \\
\text { na percepção ambiental após o } \\
\text { desenvolvimento das atividades. }\end{array}$ \\
\hline
\end{tabular}

Quadro 2 - atividades desenvolvidas no segundo semestre de execução do projeto de EA Fonte: dados da pesquisa (2018)

Ao mesmo tempo em que as atividades estavam sendo executadas em sala de aula e nos espaços da ONG, também ocorria a estruturação do espaço integrado de Educação Ambiental, composto por cisterna, composteira e horta. O espaço teve como princípio oportunizar momentos de atividades práticas em contato com o meio ambiente. O espaço funciona como um observatório onde, através dele, é possível observar as interações entre os constituintes do meio ambiente. Através da cisterna (Figura 2) foi possível reutilizar a água da chuva e, também, fazer uma ligação com a questão da poluição do arroio que se localiza próximo da ONG, chamando a atenção para a questão crítica das águas. Através da composteira (Figura 2) foi possível reduzir a quantidade de resíduos destinados para o aterro sanitário e, também, fazer uma ligação com a questão da ciclagem de nutrientes, chamando a atenção para a redução na produção de resíduos. A Figura 3 mostra crianças trabalhando com a composteira e a Figura 4 mostra que, através das hortas, foi possível fazer uma ligação da cisterna e da composteira com a questão dos alimentos e da importância de se consumir alimentos orgânicos. O espaço integrado de educação ambiental serviu para mostrar, na prática, as relações entre os constituintes do meio ambiente.

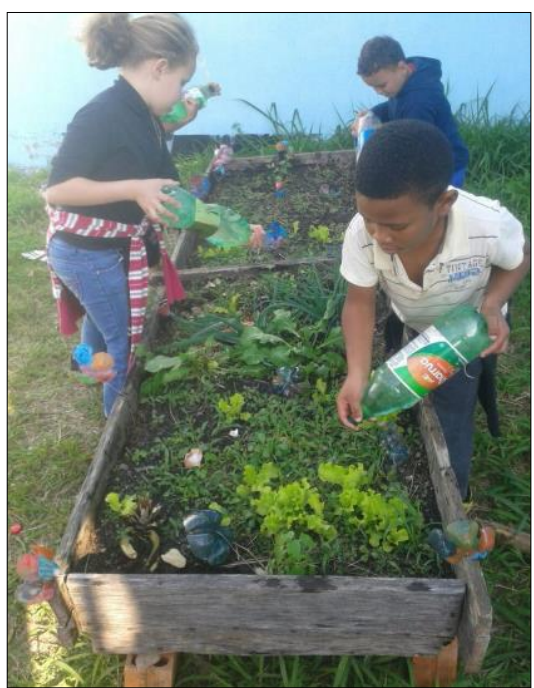

Figura 2 - Crianças utilizando a água da cisterna para regar a horta Fonte: dados da pesquisa (2017)

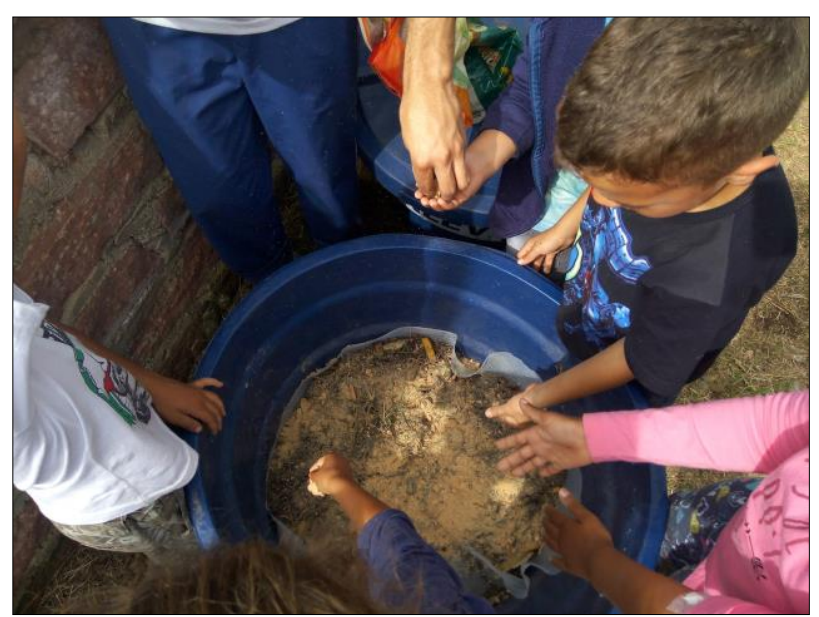

Figura 3 - Crianças utilizando a composteira Fonte: dados da pesquisa (2017) 


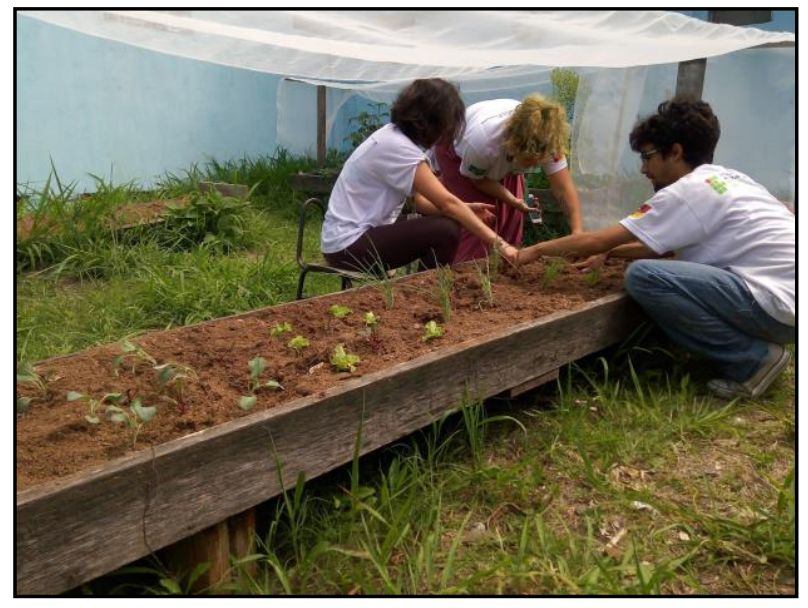

Figura 4 - Estruturação da horta Fonte: dados da pesquisa (2017)

\section{Metodologia de diagnóstico de percepção ambiental: análise dos desenhos}

A análise dos desenhos se viabilizou mediante os métodos qualitativos prescritos pela análise de conteúdo de Bardin (1977). A análise de conteúdo é uma metodologia usada para investigar e analisar o teor de todo o tipo de documentos e textos. Segundo Moraes (1999), essa análise, conduzindo a descrições sistemáticas, qualitativas ou quantitativas, ajuda a reinterpretar as mensagens e a atingir uma compreensão de seus significados, num nível que vai além de uma leitura comum. Como a análise de conteúdo não se limita a estudar apenas textos, podendo ser aplicada a uma grande variedade de materiais visuais, Moraes (1999) acrescenta que a matéria-prima da análise de conteúdo pode constituir-se de qualquer material oriundo de comunicação verbal ou não verbal, escrita ou gráfica. No caso do estudo em questão, foram utilizados os desenhos infantis. Nesse sentido, ressalta-se que, mesmo sendo criados sem a intenção documental, as representações realizadas guardam memórias e refletem conhecimentos sobre contextos sociais, configurando-se em fontes documentais, conforme enfatizado por Gobbi (2014).

Os desenhos foram realizados durante as ações de um projeto aprovado pela instituição de ensino superior vinculada. A ação realizada foi desenvolvida no âmbito do Programa de Educação Tutorial ${ }^{3}$. Para a obtenção dos desenhos foi utilizada a técnica de observação participante, por permitir contato da equipe executora com a realidade observada e obter-se informações dos sujeitos participantes em seus contextos sociais (GERHARDT et al., 2009, p. 75). Por tratar-se de uma ação que teve como base a pesquisa-ação, tomou-se o cuidado para que os aspectos éticos fossem atendidos, de forma a garantir a fidedignidade dos dados ${ }^{4}$.

Considera-se que as crianças representam o mundo a sua volta e se expressam através do desenho. Como destacado por Gurgel (2009), uma das principais funções do desenho no desenvolvimento infantil é a possibilidade que oferece de representação da realidade, sendo muito utilizado em pesquisas por permitir um maior envolvimento das crianças do que em entrevistas (TAMOUTSELI; POLYZOU, 2010).

Os desenhos evidenciam informações que vão além da mera representação dos objetos e, por isso, as interpretações do desenho infantil devem levar em consideração suas

\footnotetext{
${ }^{3}$ Cadastrado junto ao MEC e com aprovação institucional interna sob o número 267107.1417.62976.03042017.

${ }^{4}$ Ou seja, foram obtidas as prévias autorizações das instituições envolvidas, bem como a obtenção dos TCLE dos responsáveis e dos TALE pelos participantes.
} 
diferentes fases de desenvolvimento, onde, em cada fase figura um processo de evolução e amadurecimento das crianças. Lowenfeld e Brittain (1977 apud BARBOSA, 2013) explicam que: a primeira fase ocorre por volta dos dois anos de idade, e é chamada de Estágio das Garatujas; a segunda fase se inicia por volta dos quatro anos e vai até os sete anos de idade, e é chamada de Estágio Pré-Esquemático; a terceira fase se inicia aos sete anos e vai até os nove anos de idade, e é chamada de Estágio Esquemático; a quarta e última fase se inicia aos nove anos e vai até os doze anos de idade, e é chamada de Estágio de Realidade. Os educandos participantes se encontram na terceira etapa do desenvolvimento do desenho infantil, período no qual

[...] aparece uma interessante característica dos desenhos infantis: a criança dispõe os objetos que está retratando numa linha reta, em toda a largura da margem inferior da folha de papel. Assim, por exemplo, a casa é seguida de uma árvore, à qual se segue uma flor que fica ao lado da pessoa que poderá ficar antes de um cão, que é a figura final do desenho (LOWENFELD; BRITTAIN, 1977, p. 55, apud PILLOTTO; SILVA; MOGNOL, 2004, p. 5)

Essa distribuição em linha reta mostra uma lógica e uma interação entre os constituintes do desenho, demonstrando, também, que nessa fase do desenvolvimento do desenho infantil a criança já tem uma noção de espaço (Figura 5).

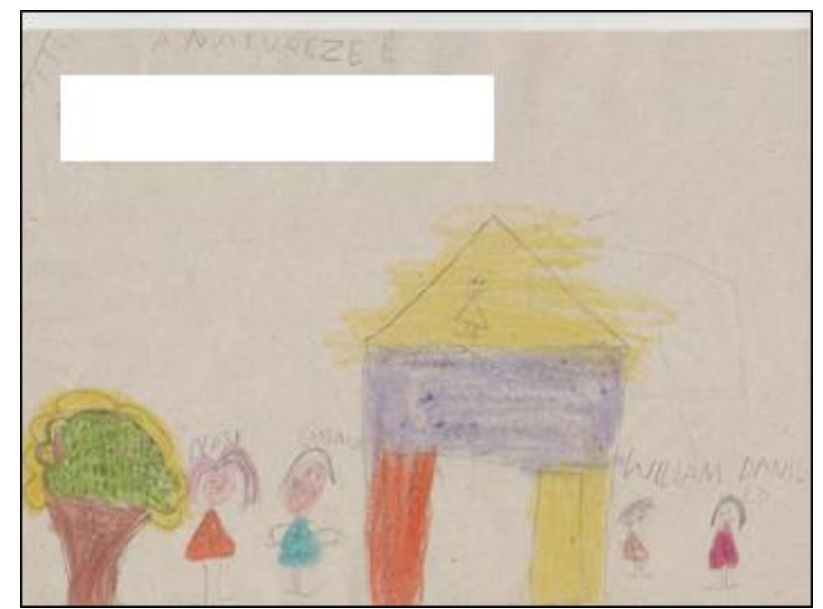

Figura 5 - Elementos dos desenhos distribuídos em linha reta, árvore, pessoas, casa e pessoas Fonte: dados da pesquisa (2017)

Como destacado por Gobbi (2014), a interpretação dos desenhos, muitas vezes, limita-se, apenas, a enquadrá-los em fases evolutivas do desenvolvimento infantil, desvalorizando a contextualização cultural, social e as situações que as crianças vivenciaram no momento de suas representações. Nesse sentido,

Seus trabalhos resultam de pesquisa pessoal, da interação com outras crianças e com o entorno social e cultural ao qual estão expostas e que ao mesmo tempo constroem. Suas criações são registros, marcas históricas deixadas por elas desde pequeninas (GOBBI, 2014, p. 156).

Dessa forma, a análise realizada pretendeu abordar alguns desenhos representados pelas crianças que participaram das atividades do projeto de educação ambiental, na tentativa de encontrar informações que permitam inferir possíveis mudanças de percepção dos educandos sobre a natureza.

Assim, tendo em vista a sua importância e representatividade, o desenho foi escolhido para realizar um diagnóstico acerca da percepção ambiental. No primeiro dia de projeto foi 
solicitado que as crianças representassem, através de um desenho, o que era natureza. No último dia de projeto, uma semana depois da última atividade, foi solicitado, novamente, para que eles representassem o que era natureza. Posteriormente, foi feita a análise dos desenhos, a fim de verificar alguma possível mudança na percepção ambiental.

Moraes (1999) destaca que a análise de conteúdo faz parte de uma busca teórica e prática, com um significado especial no campo das investigações sociais. Através dessa metodologia de pesquisa, aplicada aos desenhos, buscou-se compreender as ideias dos sujeitos através do conteúdo expresso e, assim, observar (ou não observar) uma mudança na forma como os educandos percebiam a natureza, antes e depois do projeto de educação ambiental, a partir de uma concepção transparente de linguagem (CAREGNATO; MUTTI, 2006).

Considerando os passos e a fidedignidade necessária nesse tipo de pesquisa qualitativa, optou-se por utilizar como referencial metodológico os passos apresentados por Moraes (1999) para uma abordagem indutiva-construtiva, cuja finalidade é construir uma compreensão dos fenômenos investigados. De acordo com o autor, os dados obtidos através de formas variadas de intervenção necessitam ser lapidados e tratados, visando favorecer o trabalho de compreensão, interpretação e inferência que busca a análise de conteúdo. $\mathrm{O}$ material a ser estudado necessita de uma preparação e organização para ser analisado, onde, através de uma série de etapas, é possível chegar a uma compreensão do conteúdo do material que se deseja analisar em termos de conteúdo. A seguir, apresentam-se as diferentes etapas realizadas:

\subsection{Preparação das informações}

Depois da obtenção dos desenhos, a primeira etapa é a preparação do material a ser analisado, e deve-se identificar as diferentes amostras de informação a serem analisadas. Para isso, recomenda-se uma leitura de todos os materiais e decidir quais estão, efetivamente, de acordo com os objetivos da pesquisa (MORAES, 1999). Foram obtidos 31 (trinta e um) desenhos, somando os desenhos obtidos antes e depois do projeto. Desses 31 (trinta e um) desenhos, 9 (nove) foram considerados inválidos, por não possuírem antes e/ou depois ou por não ser possível identificar o conteúdo do desenho. Sendo assim, para a análise de conteúdo foram selecionados 22 (vinte e dois) desenhos, sendo obtidos 11 (onze) antes da execução do projeto de educação ambiental e 11 (onze) obtidos após a execução do projeto.

Após selecionar a amostra a ser analisada, os desenhos foram codificados para sua rápida identificação e referência. Moraes (1999) salienta que, nessa etapa, deve-se iniciar o processo de codificação dos materiais, estabelecendo um código que possibilite identificar, rapidamente, cada elemento da amostra de depoimentos ou documentos a serem analisados. Os desenhos antes do projeto foram identificados com o número um e os desenhos após o projeto foram identificados com o número dois, além disso, cada educando recebeu um número. Sendo assim, os desenhos foram identificados com dois números, por exemplo, o educando número $11 \mathrm{fez}$ um desenho antes do projeto 1.11 (Figura 6) e outro desenho depois do projeto 2.11 (Figura 7). 


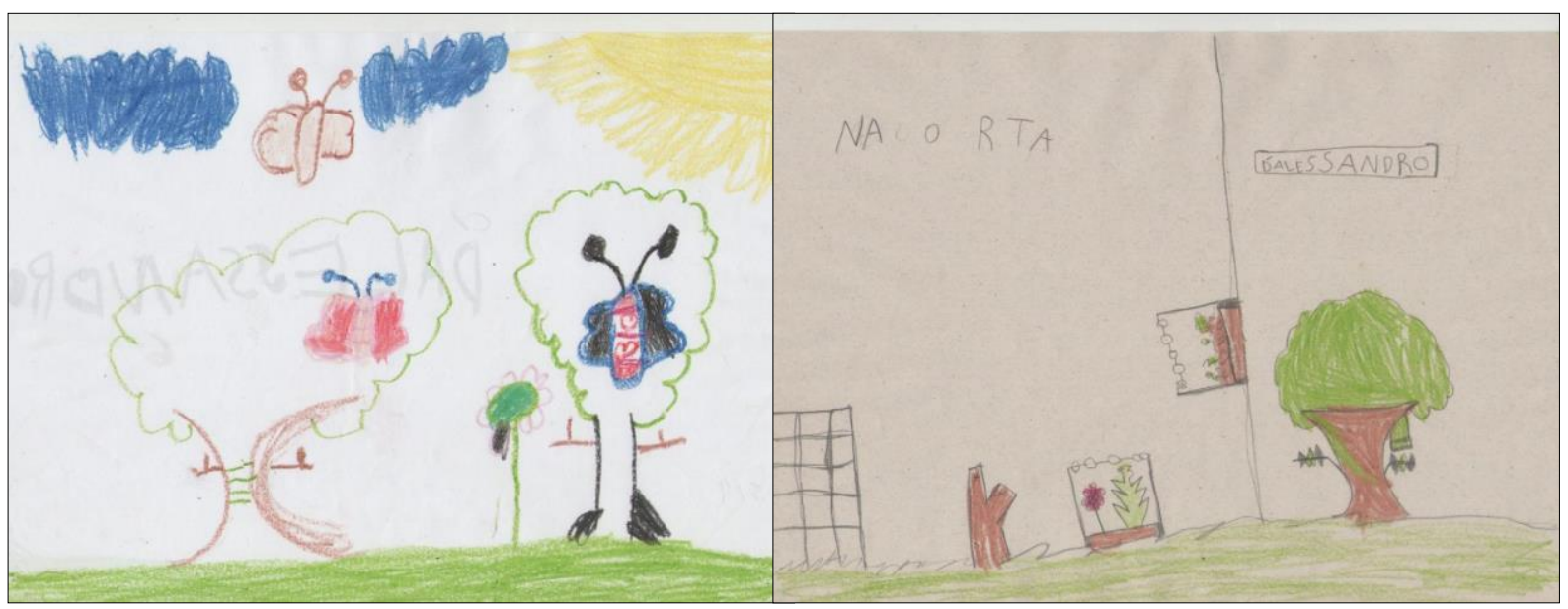

Figura 6 - Desenho 1.11

Fonte: dados da pesquisa (2017)
Figura 7 - Desenho 2.11

Fonte: dados da pesquisa (2017)

\subsection{Unitarização ou transformação do conteúdo em unidades}

Após a preparação dos desenhos, vem a etapa de unitarização, ou transformação do conteúdo em unidades, que consiste em definir a unidade de análise, para posterior classificação. Moraes (1999) define que a unidade de análise é o elemento unitário de conteúdo a ser submetido, posteriormente, à classificação. A unidade de análise pode ser um conjunto de elementos do desenho, elementos isolados do desenho, o desenho de forma integral. Destaca-se que, para a definição das unidades de análise constituintes de um conjunto de dados brutos pode-se manter os documentos ou mensagens em sua forma íntegra, ou pode-se dividi-los em unidades menores. Sendo assim, a definição da unidade é relativa à natureza do problema, dos objetivos da pesquisa e do tipo de materiais a serem analisados (MORAES, 1999).

Para o estudo em questão, a unidade de análise foi definida como sendo cada um dos elementos presentes nos desenhos. Sendo assim, foram identificados todos os elementos presentes nos desenhos: sol, céu, árvore, flor, arbusto, animais, grama, casa sem identificação, nuvem, borboleta, pássaros, animais não identificados, pessoas, referências à Casa de Nazaré (ONG), referências à horta e coração (Figura 8).

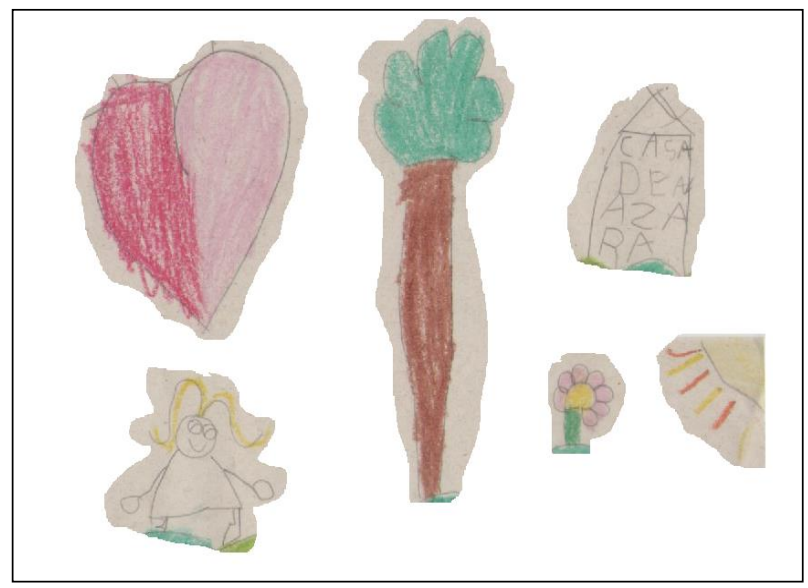

Figura 8 - Exemplo de unitarização Fonte: dados da pesquisa (2018) 


\subsection{Categorização ou classificação das unidades em categorias}

Após definidas as unidades de análise, estas foram categorizadas. Considerando-se a abordagem essencialmente indutiva-construtiva da análise em questão, as categorias emergiram ao longo do processo de análise, não tendo sido definidas a priori. Dessa forma, as categorias surgiram após a leitura/visualização e releitura de todo o material, ou seja, durante o processo, as unidades de análise foram categorizadas por semelhança. Segundo Moraes (1999), a categorização é um procedimento de agrupar dados, considerando a parte comum existente entre eles.

As unidades de análise foram classificadas em categorias:

- Vegetação: árvore, arbusto, flor, grama.

- Pessoas: representação de pessoas.

- Construções: casas sem identificação.

- Animais: pássaros, borboletas, animais não identificados.

- Sol, nuvens e céu: representações do tipo.

- Horta: alguma referência à horta, seja escrita ou desenhada.

- Coração: presença de corações nos desenhos.

- Casa de Nazaré: alguma referência à ONG onde foi realizado o projeto.

\section{Resultados e análises}

\subsection{Descrição}

Após a etapa de categorização, procede-se à etapa de descrição. Nessa etapa foi verificada a presença (ou não) das categorias nos desenhos antes e depois do projeto (Tabela $1)$.

Tabela 1 - Presença das categorias nos desenhos antes e depois do projeto.

\begin{tabular}{c|c|c}
\hline Categorias & Desenhos antes do projeto & Desenhos depois do projeto \\
\hline Vegetação & 11 & 11 \\
\hline Pessoas & 1 & 0 \\
\hline Construções & 6 & 3 \\
\hline Animais & 5 & 10 \\
\hline Sol, nuvens e céu & 11 & 6 \\
\hline Horta & 0 & 4 \\
\hline Coração & 1 & 3 \\
\hline Casa de Nazaré & 0 & \multicolumn{2}{|c}{} \\
\hline
\end{tabular}

\subsubsection{Desenhos antes do projeto}

Os desenhos antes do projeto mostram uma predominância das categorias vegetação, animais, construções e sol, nuvens e céu. Destaque para a pouca presença da categoria 
pessoas, apenas um desenho, e também da ausência das categorias horta, coração e Casa de Nazaré (Figura 9).

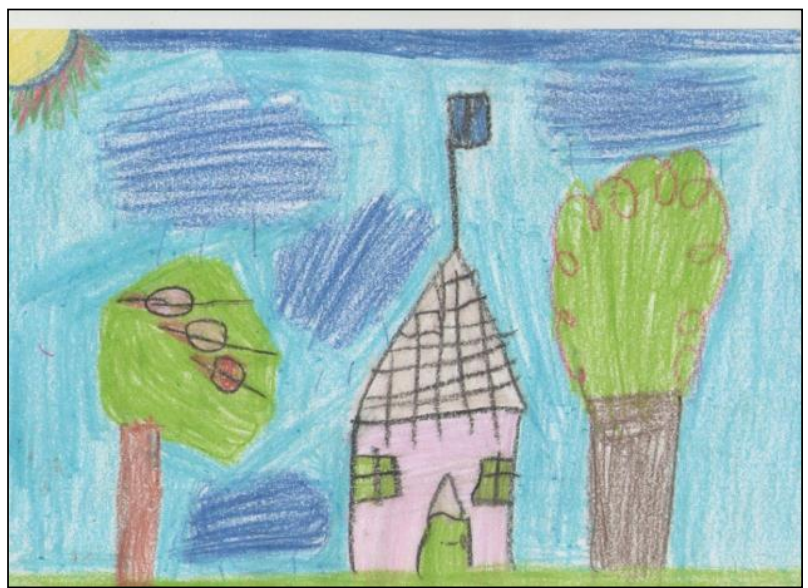

Figura 9 - Desenho típico anterior ao projeto, presença das categorias construção, vegetação e céu, sol e nuvens Fonte: dados da pesquisa (2017)

\subsubsection{Desenhos depois do projeto}

Os desenhos depois do desenvolvimento do projeto mostram uma predominância das categorias vegetação, pessoas e sol, nuvens e céu. Destaca-se o aparecimento das categorias horta, coração e Casa de Nazaré (Figura 10).

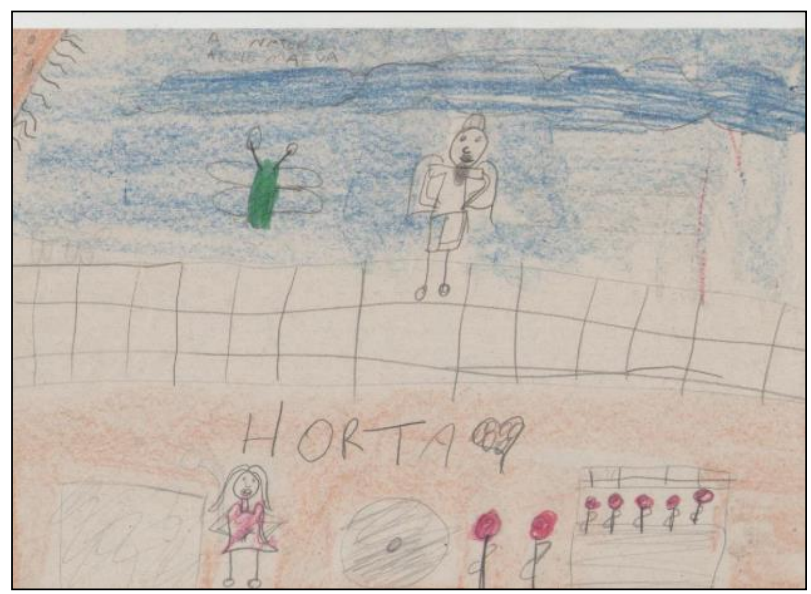

Figura 10 - Desenho típico posterior ao projeto, presença das categorias pessoas, vegetação, sol, nuvens e céu, horta e animais Fonte: dados da pesquisa (2017)

Percebe-se, claramente, que a principal diferença entre os desenhos antes e depois do projeto é a presença da categoria pessoas, onde antes do projeto verifica-se a presença em apenas um desenho e, após o projeto, a presença passa para dez desenhos.

Outro destaque reveste-se na presença da categoria construções, presente em seis desenhos antes do projeto e, após o projeto, essa categoria não apareceu em nenhum desenho. A categoria construções representa casas sem identificação. Após o projeto, surgiram as categorias horta, coração e Casa de Nazaré, que fazem referência às construções contextualizadas e identificáveis. 


\subsubsection{Comparação dos desenhos antes e depois do projeto}

Através da comparação dos desenhos realizados antes e depois do projeto de educação ambiental é possível observar que houve uma mudança na forma como as crianças abordaram a natureza. Nos desenhos $(1.1,1.3$ e 1.10) antes do projeto é possível observar uma descontextualização e ausência da categoria pessoas; após o projeto, é possível observar que aparecem desenhos $(2.1,2.3$ e 2.10) contextualizados com a realidade da comunidade e da ONG na qual estudam, além de aparecer a categoria hortas e pessoas (Figuras 11, 12, 13, 14,15 e 16).

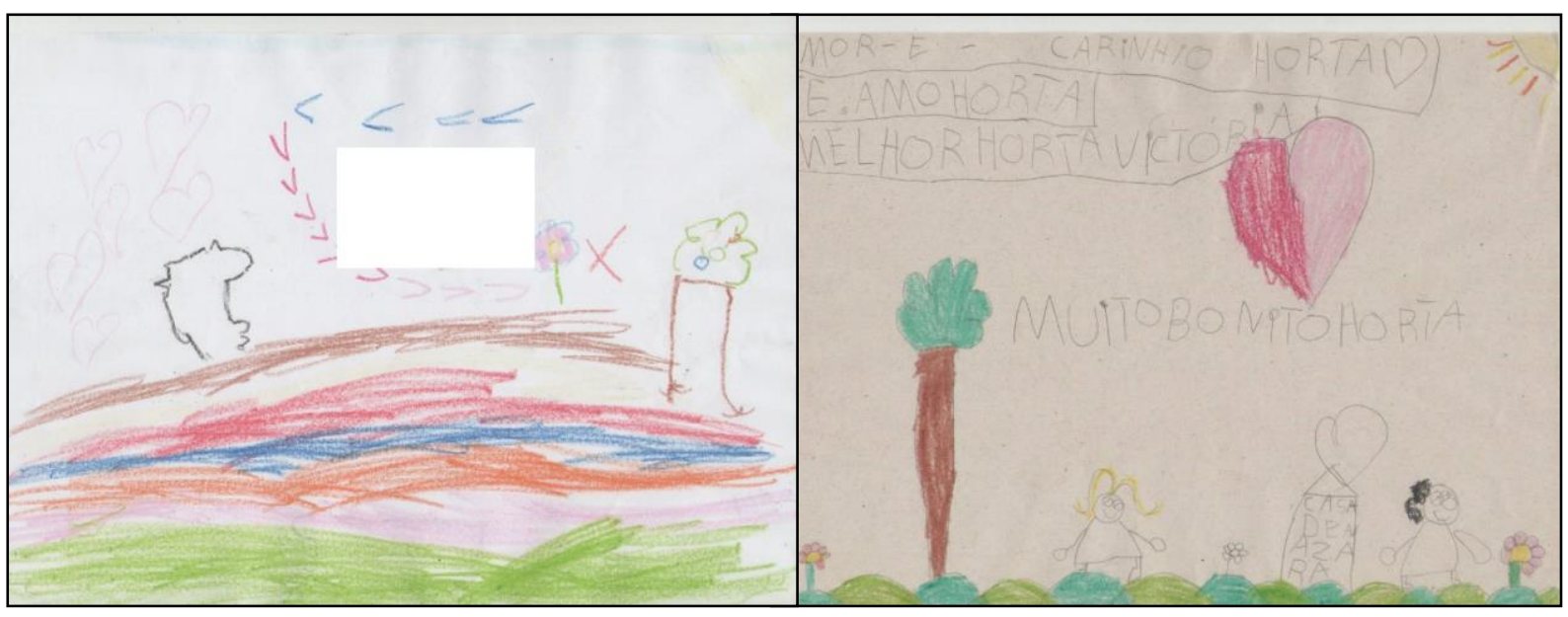

Figura 11 - Desenho 1.1

Fonte: dados da pesquisa (2017)
Figura 12 - Desenho 2.1

Fonte: dados da pesquisa (2017)

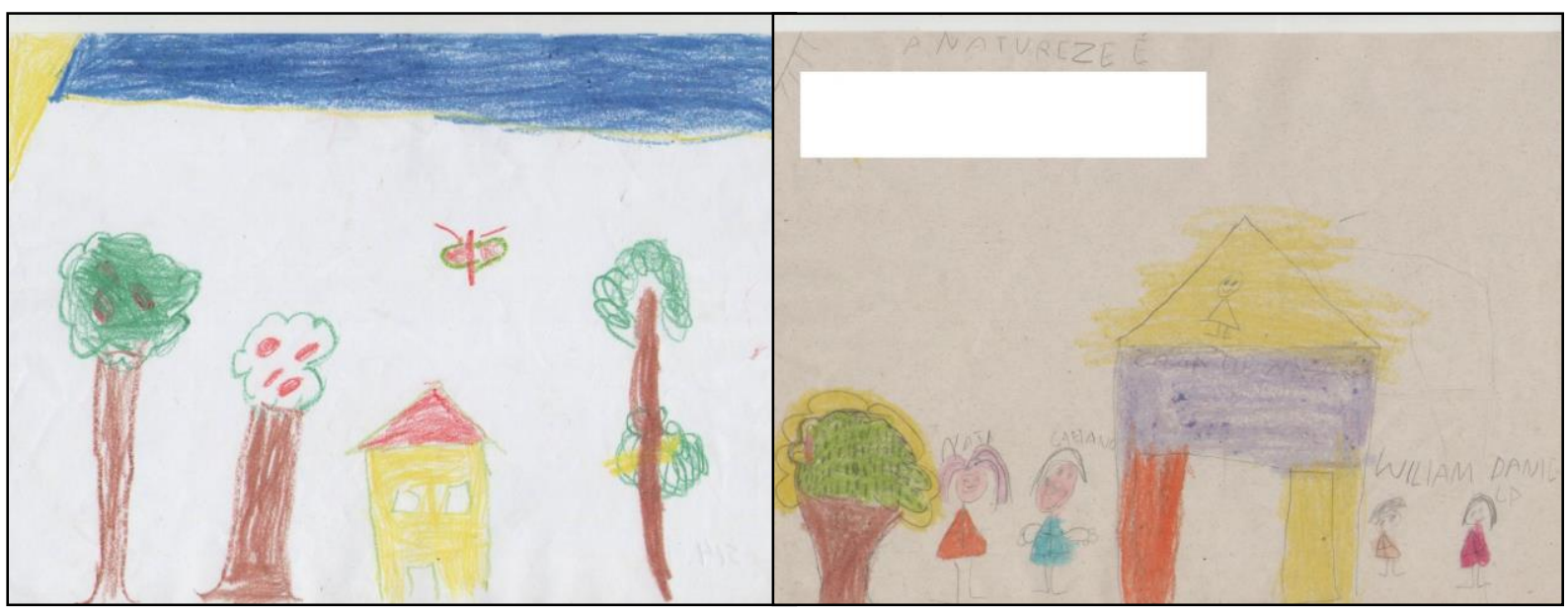

Figura 13 - Desenho 1.3

Fonte: dados da pesquisa (2017)
Figura 14 - Desenho 2.3

Fonte: dados da pesquisa (2017) 


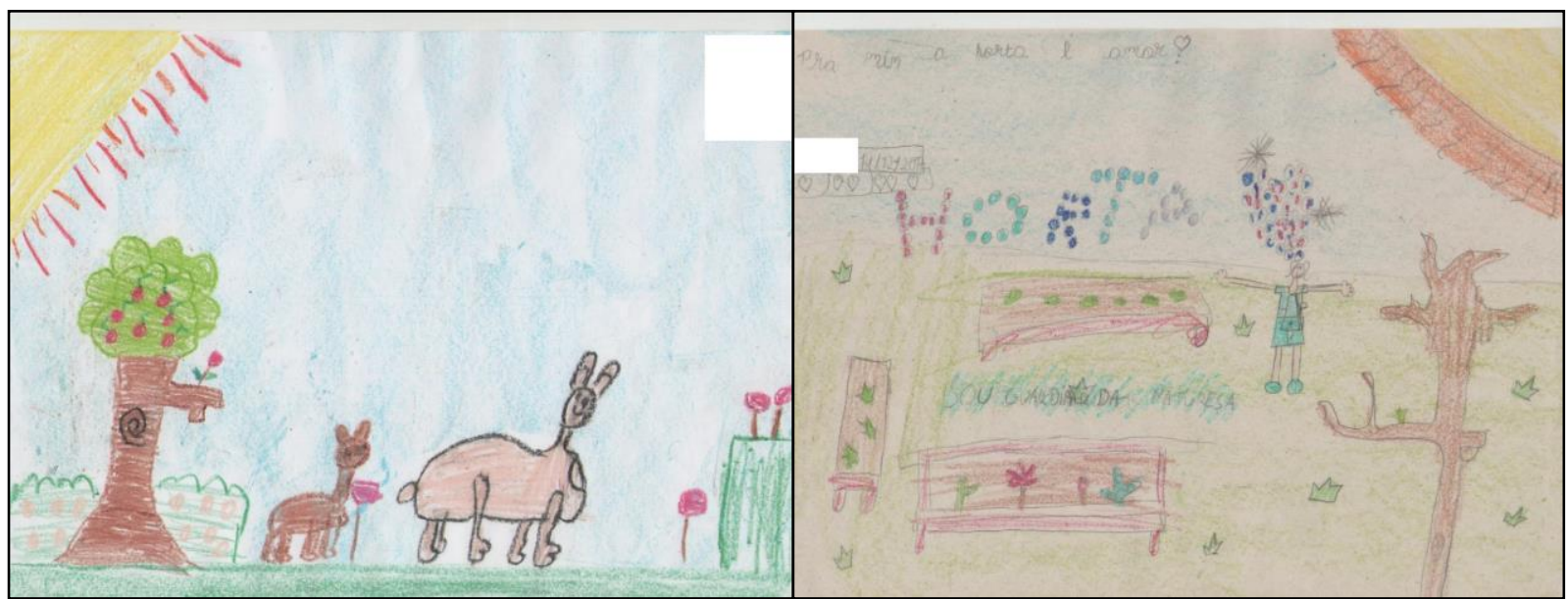

Figura 15 - Desenho 1.10

Fonte: dados da pesquisa (2017)

Figura 16 - Desenho 2.10

Fonte: dados da pesquisa (2017)

\subsection{Interpretação}

Na última etapa da análise de conteúdo, ocorre a interpretação do conteúdo estudado, buscando uma maior compreensão do significado do material. Segundo Moraes (1999), o termo interpretação está mais associado à pesquisa qualitativa, ainda que não ausente na abordagem quantitativa. Liga-se ao movimento de procura de compreensão.

É importante ressaltar que Moraes (1999) considera que para o processo de interpretação há duas possibilidades: uma delas é delimitar uma fundamentação teórica antes de realizar o processo de interpretação, ou seja, a priori. Nesses estudos a interpretação é feita através de uma exploração dos significados expressos nas categorias da análise numa contrastação com essa fundamentação. Na outra possibilidade, a fundamentação teórica define-se ao longo do processo, construída com base nos dados e nas categorias da análise. Nesse sentido, no estudo em questão, a fundamentação teórica foi definida antes de se realizar a interpretação. Para a interpretação dos desenhos foi utilizado, como referência, o livro "Interpretação do desenho infantil" do autor Di Leo (1991).

Nos desenhos anteriores ao projeto, verificou-se a predominância das categorias vegetação, animais, construções e sol, nuvens e céu. Para Di Leo (1991), desenhando para sua própria satisfação, as crianças retratam pessoas, casas, árvores, a grama, o sol. Esses temas são vistos nos trabalhos de crianças de todas as terras e culturas e atestam a universalidade básica da mente e dos sentimentos. Dentro desse contexto, cada elemento tem um significado, e segundo Di Leo (1991) a casa simboliza o lugar onde são buscados o afeto e a segurança. Animais são seguidamente adicionados como parte da família. Árvore, flores e o sol aparecem como expressão da crescente necessidade de luz e natureza.

Outra consideração importante sobre os desenhos anteriores ao projeto é que as crianças desenharam um lugar que não representa o local onde elas vivem. Na comunidade onde moram e onde foi realizado o projeto existem moradias bem simples, casas aglomeradas e resíduos (Figura 17). Nos desenhos foram representados lugares com vegetação esparsa, casas grandes e isoladas (Figura 18). 


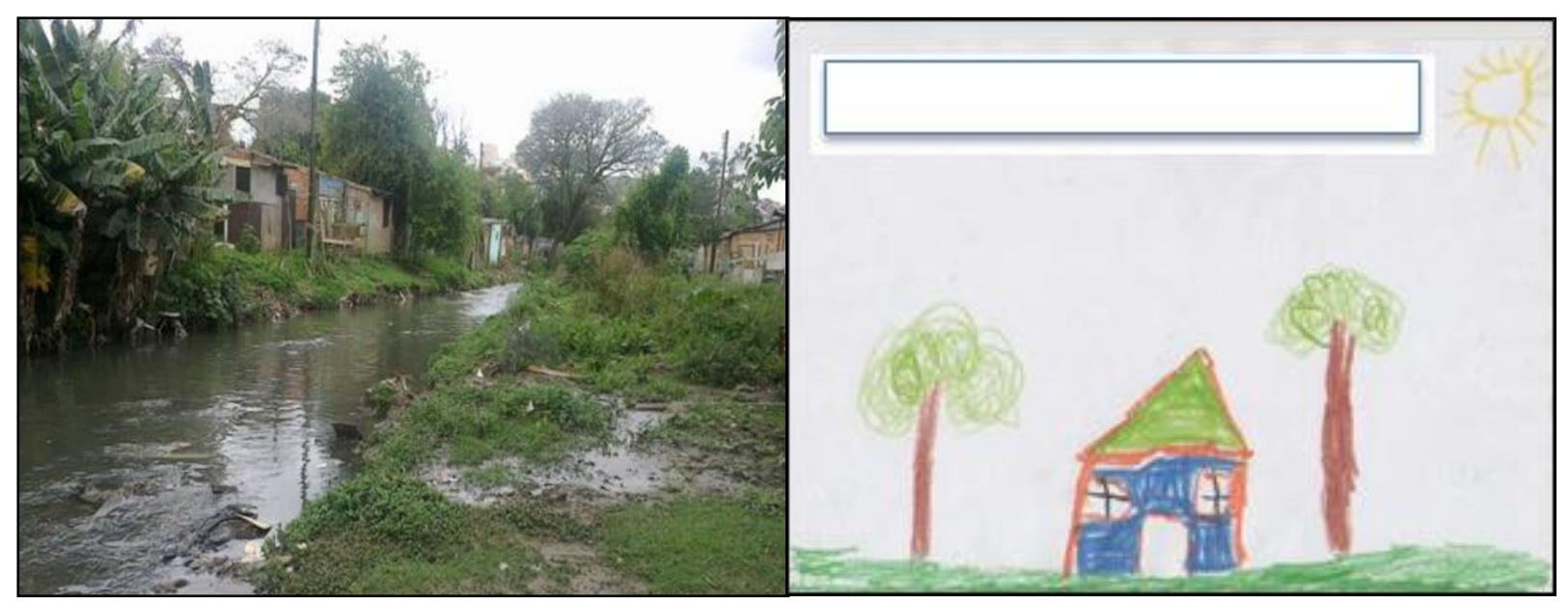

Figura 18 - Desenho antes ao projeto

Fonte: dados da pesquisa (2017)

Figura 17 - Foto da comunidade

Fonte: dados da pesquisa (2017)

Sobre essas questões, Di Leo (1991) percebeu, em seus estudos, que crianças que moram em cidade, na sua maioria, desenham casas que são típicas da vida campestre, longe da sua realidade pois moram em prédios, o que demonstra, assim, o interesse e a necessidade de um outro estilo de vida.

Goldberg, Yunes e Freitas (2005) discorrem acerca da aplicabilidade na utilização de desenhos como representações que podem ser utilizadas como indicadores de avaliação das atividades de educação ambiental. Nos desenhos posteriores ao projeto, as representações de construções e a pouca presença da categoria pessoas foi substituída pela presença, em quase todos os desenhos, da categoria pessoas e o surgimento das categorias hortas, coração e casa de Nazaré (Figura 19). Tal fato permite inferir, assim, uma relação de afeto e pertencimento com a Horta, a Casa de Nazaré e com os com colegas de turma, ou seja, com o seu contexto. Pode-se compreender, também, que as crianças estavam, naquele momento, retratando a própria realidade e não mais um desejo de como gostariam que fosse a realidade. A natureza ali representada está retratada na relação deles com o espaço em que vivem e dentro do seu contexto.

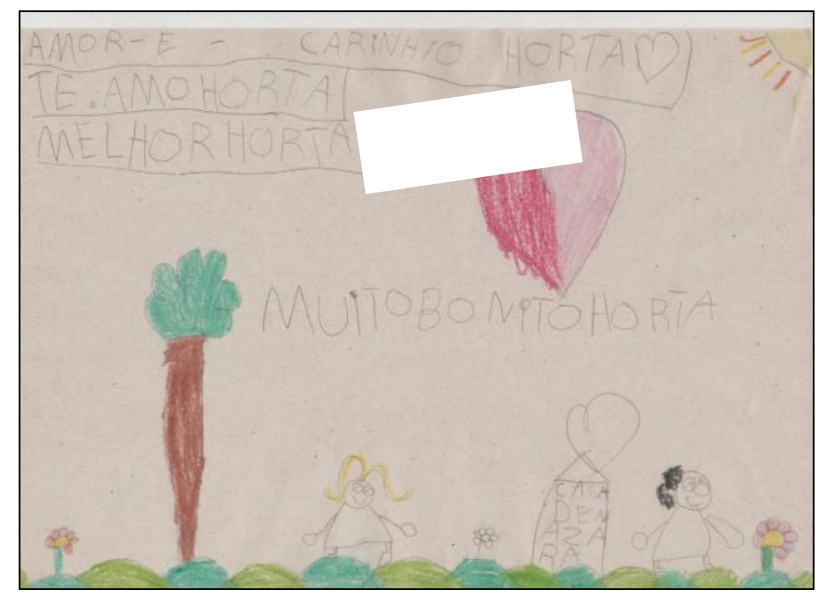

Figura 19 - Desenho posterior ao projeto Fonte: dados da pesquisa (2017)

Merece destaque que a categoria coração não foi representada antes da execução do projeto e, depois da execução apareceu em quatro desenhos, mostrando a influência das 
atividades realizadas. Uma das atividades de encerramento das ações do projeto foi a construção, junto com os educandos, de um mural de tampinhas de garrafa PET, em formato de coração (Figura 20), que teve como objetivo incluir os educandos na construção do espaço e debater a reciclagem, o que foi representado em quatro desenhos (Figura 21).

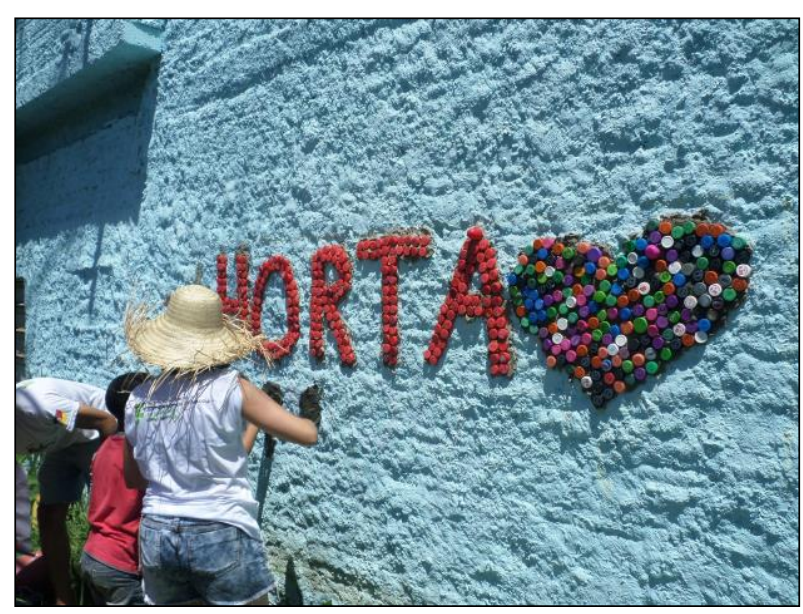

Figura 20 - Mural de tampinha de garrafa PET Fonte: dados da pesquisa (2017)

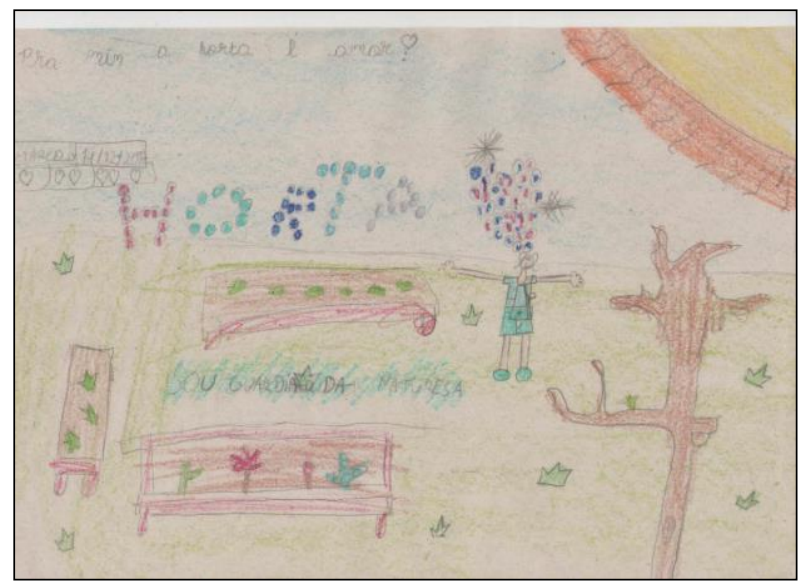

Figura 21 - Representação do mural de tampinha de garrafa PET Fonte: dados da pesquisa (2017)

As atividades de educação ambiental buscaram resgatar essa relação com o meio ambiente, contextualizando-o com a realidade deles, onde as atividades foram desenvolvidas no espaço da ONG, destacando a relação sistêmica que existe entre os educandos e o meio ambiente. Buscou-se uma perspectiva interpretativa, na qual, segundo Carvalho (2017), ambiente é o lugar das inter-relações entre sociedade e natureza.

\section{Considerações finais}

A relação dos indivíduos com a natureza se transformou, com o passar do tempo, e o modo como os indivíduos se relacionam com o meio ambiente pode se modificar ao longo da vida. Sendo assim, o estudo de percepção ambiental se apresenta essencial para o planejamento de ações de educação ambiental que visam contribuir para o processo de Gestão Ambiental e, também, para o resgate da relação entre ser humano e natureza.

Este estudo evidenciou que a utilização dos desenhos infantis pode ser uma ferramenta de diagnóstico de percepção ambiental eficaz no contexto da educação ambiental. Por meio da análise dos desenhos foi possível diagnosticar uma mudança na percepção 
ambiental dos educandos, antes e depois do projeto implantado. Como exemplo, antes do projeto poucos educandos representaram a presença humana na natureza - que surgiu apenas em um desenho; depois do projeto, figuras humanas foram representadas em dez desenhos, mostrando, assim, que os sujeitos passaram a se perceber como parte integrante da natureza. Os educandos, anteriormente ao projeto, representaram uma realidade que não era a deles, mas que era vista como um ideal de natureza, uma casa grande e com grandes árvores; depois do projeto, passaram a representar a ONG Casa de Nazaré juntamente com o espaço da horta, apropriando-se desses espaços e demonstrando, assim, a importância das atividades realizadas em locais além da sala de aula, como as atividades realizadas no pátio, e também no espaço integrado de EA constituído durante as ações.

É importante levar em consideração que se trata apenas da identificação de mudanças iniciais, tendo em vista que a educação ambiental é um processo contínuo, em permanente construção. Nesse primeiro momento, foram abordadas questões locais e, conforme o período escolar for avançando, questões mais complexas, regionais e globais vão sendo incluídas nas discussões e ações.

Podemos concluir, também, que através da execução do projeto de educação ambiental a relação e a percepção ambiental dos educandos mudaram, passando de uma percepção ambiental descontextualizada da realidade, onde eles não se enxergavam como parte do meio ambiente, para uma percepção ambiental contextualizada e participativa do meio ambiente. Complementando essa questão, Carvalho aponta que:

\footnotetext{
Nesse sentido, a interação com o ambiente ganha o caráter de um autêntico diálogo, na qual aquele se oferece como um contexto do qual fazemos parte, envolvidos que somos pelas condições ambientais, ao mesmo tempo em que nós, como seres simbólicos e portadores de linguagem, produzimos nossa visão e nossos recortes dessa realidade, construindo percepções, leituras e interpretações do ambiente que nos cerca (CARVALHO, 2009, p. 155).
}

Destaca-se, também, que o presente estudo demonstrou que a utilização de métodos quali-quantitativos, a partir da análise de conteúdo, mostraram-se adequados para identificar mudanças, aparentemente sutis, mas significativas, na percepção ambiental dos envolvidos. Por fim, podemos destacar a importância dos métodos avaliativos para a melhoria contínua dos processos de Educação e Gestão Ambiental.

\section{Referências}

ALVES, H. P. F. Vulnerabilidade socioambiental na metrópole paulistana: uma análise sociodemográfica das situações de sobreposição espacial de problemas e riscos sociais e ambientais. Rev. bras. estud. popul., São Paulo, v. 23, n.1, p.43-59, 2006. Disponível em: <https://doi.org/10.1590/S0102-30982006000100004>. Acesso em: 06 fev. 2021.

BARBOSA, M. S. Grafismo Infantil - Estágios do desenho segundo Lowenfeld e Luquet. Roda de Infância, 2013. Disponível em: http://rodadeinfancia.blogspot.com/2013/07/grafismo-infantilestagios-do-desenho.html. Acesso em 08 fev. 2021.

BARDIN, L. Análise de Conteúdo. Lisboa: Edições 70, 1977. Disponível em: <https://www.ets.ufpb.br/pdf/2013/2\%20Metodos\%20quantitat\%20e\%20qualitat\%20$\%$ 20IFES/Bauman,\%20Bourdieu,\%20Elias/Livros\%20de\%20Metodologia/Bardin\%20\%201977\%20-\%20An\%C3\%A1lise\%20de\%20Conte\%C3\%BAdo.pdf>. Acesso em: 06 fev. 2021. 
BEHLING, G. M.; GIL, R. L.; CARLAN, F. A. Um panorama da constituição da Educação Ambiental enquanto campo no Brasil. In: KUSS, A.V et al. (Orgs.). Possibilidades metodológicas para a pesquisa em educação ambiental. Pelotas: Editora e Cópias Santa Cruz, 2015. p. 14-24.

BRASIL. Lei $n^{o}$ 6.938, de 31 de agosto de 1981. Dispõe sobre a Política Nacional do Meio Ambiente, seus fins e mecanismos de formulação e aplicação, e dá outras providências. Brasília: Casa Civil, 1981. Disponível em: <http://www.planalto.gov.br/ccivil_03/leis/16938.htm>. Acesso em: 06 fev. 2021.

CAREGNATO, R. C. A.; MUTTI, R. Pesquisa qualitativa: análise de discurso versus análise de conteúdo. Texto contexto - enferm., Florianópolis, v.15, n.4, p.679-684, 2006. Disponível em: <https://doi.org/10.1590/S0104-07072006000400017>. Acesso em: 06 fev. 2021.

CARVALHO, I. C. M. Paisagem, historicidade e ambiente: as várias naturezas da natureza. Confluenze: Rivista di Studi Iberoamericani, Bolonha, v. 1, n. 1, p. 136-157, 2009. Disponível em: <https://confluenze.unibo.it/article/view/1420>. Acesso em 06 fev. 2021.

CARVALHO, I. C. M. Educação ambiental: a formação do sujeito ecológico. São Paulo: Cortez Editora, 2017.

DI LEO, J. H. A interpretação do desenho infantil. Tradução de Marlene Neves Strey. 3 ed. Porto Alegre: Artes Médicas, 1991.

ESTEVES, C. J. O. Risco e vulnerabilidade socioambiental: aspectos conceituais. Caderno IPARDES-Estudos e Pesquisas, Curitiba, v. 1, n. 2, p. 62-79, 2011. Disponível em: <http://www.ipardes.gov.br/ojs/index.php/cadernoipardes/article/view/421>. Acesso: em 06 fev. 2021.

FIGUEIREDO, A. D. A Pedagogia dos contextos de aprendizagem. Revista e-Curriculum, São Paulo, v. 14, n. 3, p. 809-836, 2016. Disponível em:

<https://revistas.pucsp.br/index.php/curriculum/article/view/28989>. Acesso: em 06 fev. 2021.

FREIRE, P. A importância do ato de ler: em três artigos que se completam. 45 ed. São Paulo: Cortez Editora, 1992.

GADOTTI, M. Pedagogia da práxis. In: FERRARO JÚNIOR, L. A. (Coord.). Encontros e Caminhos: formação de educador(es) ambientais e coletivos educadores. Brasília: Ministério do Meio Ambiente, 2005. p. 239-244.

GERHARDT, T. E.; RAMOS, I. C. A.; RIQUINHO, D. L.; SANTOS, D. L. Unidade 4 - Estrutura do projeto de pesquisa. In: GERHARDT, T. E.; SILVEIRA, D. T. (Orgs.). Métodos de pesquisa. Porto Alegre: Editora da UFRGS, 2009. p. 65-87.

GOOGLE. Google Maps. Localização do Bairro Cristal no município de Porto Alegre. Disponível em: <https://www.google.com.br/maps/place/Cristal,+Porto+Alegre+-+RS/@-30.0443571,$51.2267404,14605 \mathrm{~m} /$ data $=! 3 \mathrm{~m} 1$ ! $1 \mathrm{e} 3$ ! $4 \mathrm{~m} 5 ! 3 \mathrm{~m} 4$ ! 1s0x95198274fc916a63:0x480b68bd7a640722!8m 2!3d-30.0877743!4d-51.2397694>. Acesso em: 17 jun.2021.

GOBBI, M. A. Imaginação, culturas e fontes documentais em desenhos de meninas e meninos da Educação Infantil brasileira. Studi sulla formazione, Firenze, v. 1, [s.n], p. 151-164, 2014. Disponível em: <https://core.ac.uk/reader/228533470>. Acesso em 06 fev. 2021. 
GOLDBERG, L. G.; YUNES, M. A. M.; FREITAS, J. V. F. O desenho infantil na ótica da ecologia do desenvolvimento humano. Psicologia em estudo, Maringá, v. 10, n. 1, p.97-106, 2005. Disponível em: <https://doi.org/10.1590/S1413-73722005000100012〉. Acesso em 06 fev. 2021.

GUIMARÃES, M. Educação ambiental crítica. In: LAYRARGUES, P. P. (Coord). Identidades da educação ambiental brasileira. Brasília: Ministério do Meio Ambiente, 2004. p. 25-34.

GURGEL, T. O desenho e o desenvolvimento das crianças. Portal Nova escola, online, $01 \mathrm{dez}$ 2009. Ed. 228. Disponível em: $<$ https://novaescola.org.br/conteudo/121/o-desenho-e-odesenvolvimento-das-criancas>. Acesso em: 17 jun. 2021.

LOUREIRO, C. F. B. Educação Ambiental e movimentos sociais na construção da cidadania ecológica e planetária. In: LOUREIRO, C. F. B.; LAYRARGUES, P. P.; CASTRO, R. S. (Orgs.) Educação ambiental: repensando o espaço da cidadania. 2 ed. São Paulo: Cortez, 2002. p. 69-98.

LOUREIRO, C. F. B. Educação ambiental transformadora. In: LAYRARGUES, P. P. (Coord). Identidades da educação ambiental brasileira. Brasília: Ministério do Meio Ambiente, 2004. p. 6584. Disponível em: <https://smastr16.blob.core.windows.net/cea/cea/ident_eabras.pdf>. Acesso: em 06 fev. 2021.

LUCCAS, M. B.; BONOTTO, D. M. B. Educação ambiental na educação infantil: algumas contribuições. Pesquisa em Educação Ambiental, Rio Claro, v. 12, n. 2, p. 10-23, 2017. Disponível em: <https://doi.org/10.18675/2177-580X.vol12.n2.p10-23>. Acesso em: 06 fev. 2021.

MAZOYER, M.; ROUDART, L. História das agriculturas no mundo. Do Neolítico à crise contemporânea. São Paulo: Editora UNESP, 2010.

MORAES, R. Análise de conteúdo. Revista Educação, Porto Alegre, v. 22, n. 37, p. 7-32, 1999. Disponível em: $<$ http://pesquisaemeducacaoufrgs.pbworks.com/w/file/fetch/60815562/Analise\%20de\%20conte\%C 3\%BAdo.pdf >. Acesso em: 06 fev. 2021

OXFAM - Oxford Committe for Famine Relief 2018. Relatório Compensem o trabalho e não a riqueza. São Paulo: Oxfam Brasil, 2018. Disponível em: <https://www.oxfam.org.br/justica-sociale-economica/forum-economico-de-davos/recompensem-o-trabalho-nao-a-riqueza/>. Acesso em: 06 fev. 2021.

PALMA, I. R. Análise da percepção ambiental como instrumento ao planejamento da educação ambiental. 2005. Dissertação (Mestrado em Engenharia de Minas, Metalúrgica e de Materiais) Universidade Federal do Rio Grande do Sul, Porto Alegre, 83p. 2005.

PEDRINI, A.; COSTA, É. A.; GHILARDI, N. Percepção ambiental de crianças e pré-adolescentes em vulnerabilidade social para projetos de educação ambiental. Ciência \& Educação, Bauru, v. 16, n. 1, p. 163-179, 2010. Disponível em: 〈http://dx.doi.org/10.1590/S1516-73132010000100010>. Acesso em: 06 fev. 2021.

PILLOTTO, S. S. D.; SILVA, M. K.; MOGNOL, L. T. Grafismo infantil: linguagem do desenho. Revista Linhas, Florianópolis, v. 5, n. 2, p. 1-9, 2004. Disponível em: <https://www.revistas.udesc.br/index.php/linhas/article/view/1219/1033>. Acesso em: 17 jun. 2021.

QUINTAS, J. S. Educação no processo de gestão ambiental: uma proposta de educação ambiental transformadora e emancipatória. In: LAYRARGUES, P. P. (Coord). Identidades da educação ambiental brasileira. Brasília: Ministério do Meio Ambiente, 2004. p. 113-140. 
QUINTAS, J. S. Introdução à gestão ambiental pública. Brasília: Ibama, 2005.

REGO, A. P. Lei complementar $n^{o}$. 140/11: inovações em relação ao processo administrativo ambiental brasileiro. 2013. Trabalho de conclusão de curso (Bacharelado em Direito) -

Universidade de São Paulo, São Paulo, 130p. 2013. Disponível em:

<http://www.tcc.sc.usp.br/tce/disponiveis/89/890010/tce-27112013-143011/?\&lang=br >. Acesso em: 30 abr. 2020.

SANTOS, M. A questão do meio ambiente: desafios para a construção de uma perspectiva transdisciplinar. GeoTextos, Salvador, v. 1, n. 1, p. 139-151, 2005. Disponível em: http://dx.doi.org/10.9771/1984-5537geo.v1i1.3033. Acesso em: 17 jun. 2021.

SATO, M. Apaixonadamente Pesquisadora em Educação Ambiental. Educação: Teoria e Prática, Rio Claro, v. 9, n. 16/17, p. 24-35. 2001. Disponível em:

<http://www.revistaea.org/artigo.php?idartigo=108>. Acesso em: 06 fev. 2021.

SAUVÉ, L. Uma cartografia das correntes em educação ambiental. In: SATO, M.; CARVALHO, I. (Orgs.). Educação Ambiental: pesquisa e desafios. Porto Alegre: Artmed, 2005. p. 17-44.

SILVA, R. L. Análise da percepção ambiental, por meio de desenhos, de alunos do ensino fundamental numa escola da zona rural, Chapadinha-MA. Trabalho de Conclusão de Curso (Bacharelado e licenciatura em Ciências Biológicas) - Centro de Ciências Agrárias e Ambientais, Universidade Federal do Maranhão, Chapadinha, 32p. 2017. Disponível em:

<https://rosario.ufma.br/jspui/handle/123456789/1464>. Acesso em: 06 fev. 2021.

SCHWANKE, C.; CADEI, M. S. Educação Ambiental. In: SCHWANKE, C. (Org). Educação Ambiental - Conhecimentos e Práticas. Porto Alegre: Bookman, 2013. p. 56 - 75.

TAMAIO, I. A Mediação do professor na construção do conceito de natureza: uma experiência de Educação Ambiental na Serra da Cantareira e Favela do Flamengo - São Paulo/SP. Dissertação (Mestrado em Educação Aplicada às Geociências) - Universidade Estadual de Campinas, Campinas, 153p. 2000.

TAMOUTSELI, N; POLYZOU. E. Using Drawings to Assess Children's Perceptions of Schoolyard Environment: A Case Study of a Primary School in Drama, Greece. In: WSEAS INTERNATIONAL CONFERENCE ON ENGINEERING EDUCATION, 7, 2010, Varna. Proceedings. Varna: ACM Digital Libary Home, 2010. p. 54-57. Disponível em: https://dl.acm.org/doi/10.5555/1864181.1864195. Acesso em: 03. abr. 2020.

TRISTÃO, M.; FASSARELLA, R. C. Contextos de aprendizagem. In: FERRARO JUNIOR, L. A. (Org.). Encontros e caminhos: formação de educadoras (es) ambientais e coletivos educadores. Brasília: MMA, 2007. p. 87-94. (Vol. 2)

UHMANN, R. I. M.; VORPAGEL, F. S. Educação ambiental em foco no ensino básico. Pesquisa em Educação Ambiental, Rio Claro, v. 13, n. 2, p. 53-68, 2018. Disponível em:

<https://doi.org/10.18675/2177-580X.vol13.n2.p53-68>. Acesso em: 06 fev. 2021.

UNESCO - Organização das Nações Unidas para a Educação, Ciência e Cultura. Carta da Terra. Brasília: Unesco Brasil, 2002. Disponível em: <https://revistas.pucsp.br/pensamentorealidade/article/viewFile/8497/6302>. Acesso em: 17 jun. 2021.

VILLAR, L. M. ; ALMEIDA A. J.; LIMA, M. C. A.; ALMEIDA, J. L. V.; SOUZA, L. F. B.; PAULA, V. S. A percepção ambiental entre os habitantes da região noroeste do estado do Rio de 
Pesquisa em Educação Ambiental, vol.16, n.1, 2021 DOI: http://dx.doi.org/10.18675/2177-580X.2021-14985

Janeiro. Escola Anna Nery Revista de Enfermagem, Rio de Janeiro, v. 12, n. 2, p. 285-290, 2008.

Disponível em: <http://dx.doi.org/10.1590/S1414-81452008000200013〉. Acesso em: 07 fev. 2021. 